\title{
Nominal Tonology and Spreading Rules in Tagbana (Frò?ò dialect)
}

\author{
Annie Rialland, Yranahan Traoré, Caroline Féry \\ Université Sorbonne Nouvelle and Goethe-Universität
}

\begin{abstract}
This article investigates nominal tonology of Tagbana, a Senufo language of Côte d'Ivoire. The contribution is twofold: first, it concerns the whole tonal system, including lexical tones and sandhi tone rules, and second it relates the tonal system to the prosodic hierarchy. Tagbana has three level tones (L, M, H) and two floating tones $(\mathrm{H})$ and $(\mathrm{L})$. A mid tone (M) at the end of a noun is always followed by a floating tone (either $\mathrm{H}$ or $\mathrm{L}$ ) that might be a historic trace left by the tone of a Class Marker. Active sandhi tonal rules are called 'Mid Replacement' (RepM), 'Low Raising' (RaisL), 'Spreading of L' (SprL) \& 'Spreading of H' (SprH). The domains of the sandhi tonal rules include the Minimal Prosodic Word (root + class marker), the Intermediate and Maximal Prosodic Words (nominal and adjectival compounds), the Prosodic Phrases (particularly in object + verb constructions), and the Intonational Phrase. From the Minimal Prosodic Word on, it was found that a larger number of tonal sandhi processes apply in smaller prosodic domains, and that the higher the prosodic domain, the fewer processes are active.
\end{abstract}

Keywords: Tonal system, Tagbana, floating tones, sandhi rules, prosodic structure

\section{Introduction}

In this article, nominal tonology is examined in Tagbana, and more especially Frò?ò, a dialect spoken around the town of Fronan of which the second author is a native speaker. Previous publications on Tagbana includes a grammar sketch (Clamens 1952), a lexicon (Katia Kamara 1988), studies of specific topics, such as the grammar and meaning of Class Markers (Kone 2015), the phonology and morphology of the nominal domain (Traore 2020) and the syllable structure (Traoré \& Féry 2018). None of them consider tone spreading rules, and none of them identify floating tones.

The present study of spreading rules sheds a new light on the whole tonal system, as it provides evidence for floating tones, for 'indivisible' tonal patterns, and for complex $\mathrm{M}$ tones patterns with either a floating $(\mathrm{H})$ or a floating $(\mathrm{L})$ appendix.

It is also shown that clusters of tonal rules apply in prosodic constituents that are mapped to morpho-syntactic constituents. One of the most significant claims of this article is that in Tagbana, the number of tonal spreading rules as well as their nature are related to the nature of the prosodic constituent in which they apply. Considering the prosodic levels above the simple Prosodic Word, we will see that the smaller the prosodic constituent is, the more tonal sandhi processes are found, at least in the nominal domain. For Tagbana, we introduce a recursive model of prosodic constituency, in line with Ladd's pioneering work (1986) and with Ito \& Mester's (2013) implementation of recursive prosodic structure, illustrated in (8). The paper starts with an overview of the lexical tones of Tagbana and of the prosodic hierarchy in this introductory section. Section 2 passes review of the tonal phenomena in the Prosodic Word, Section 3 investigates the tones in the Prosodic Phrase and Section 4 briefly describes the boundary tones of the Intonation Phrase. 


\subsection{Tones and lexical tones}

1.1.1 Background on tones. Tagbana has three level tones, high $\mathrm{H}$, mid M, and low L, as previously assumed for Tagbana (Clamens 1952, Katia Kamara 1988, Kone 2015 and Traoré 2020). The tone bearing unit (TBU) is the syllable and any syllable can bear a $\mathrm{L}, \mathrm{H}$, or M tone, indicated in the examples by an acute accent, a grave accent and a macron respectively. Besides the three level tones linked to syllables, Tagbana has two floating tones, a floating $\mathrm{L}$ and a floating $\mathrm{H}$. These floating tones are indicated in parentheses: $(\mathrm{H})$ and $(\mathrm{L})$. There is no floating $\mathrm{M}$ tone.

Remarkably, no noun ends in a simple $M$ tone while verbs can (see 3.1.). At the end of a noun, $M$ is always followed either by a floating $(H)$ or a floating $(L)$, see (1). These floating tones are made particularly visible in replacement and spreading rules, being realized on following words (see Sections 2, 3 and 4).

(1) Mid tone nouns ending with $\mathrm{M}(\mathrm{H})$ or $\mathrm{M}(\mathrm{L})$

a. $\mathrm{M}(\mathrm{H})$

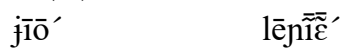

'house' 'big mamba'

b. $\mathrm{M}(\mathrm{L})$

$\begin{array}{ll}\text { nũ } & \text { 'jī̄' } \\ \text { 'mother' } & \text { 'older sister' }\end{array}$

The floating tones also influence the realization of the words in isolation. Words ending with $\mathrm{M}(\mathrm{H})$ are realized with a flat contour in isolation (Figure 1a and 1b).

Figure 1. Fo curves of nouns ending with $\mathrm{M}(\mathrm{H})$ as pronounced in isolation: a) $[\dot{j} \bar{\imath} \bar{o}] j^{j} \bar{\imath} \bar{o}^{\prime}$

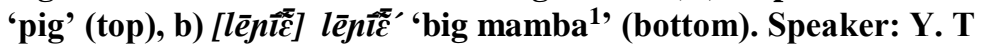

a. A monosyllabic word ending in $\mathrm{M}(\mathrm{H})$

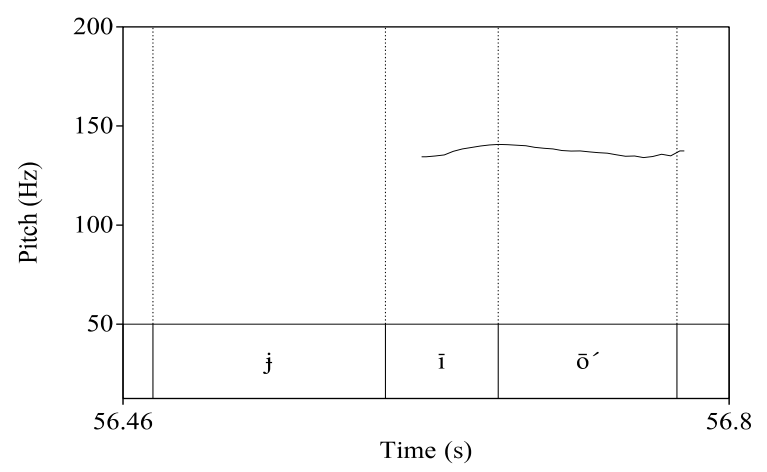

${ }^{1}$ Mamba is a type of venomous snake. 
b. A disyllabic word ending in $\mathrm{M}(\mathrm{H})$

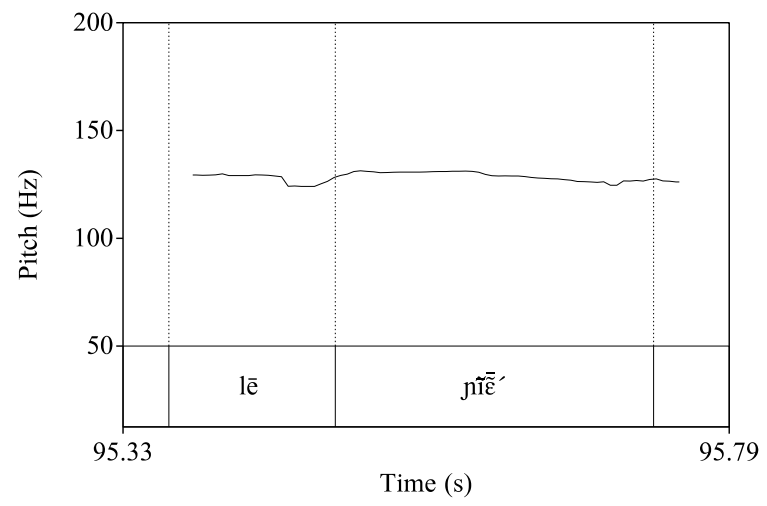

By contrast, nouns with final $\mathrm{M}(\mathrm{L})$ are realized rather flat if they are monosyllabic and otherwise with a lowering of the final $\mathrm{M}$ tone (Figure $2 \mathrm{a}$ and $2 \mathrm{~b}$ ). ${ }^{2}$

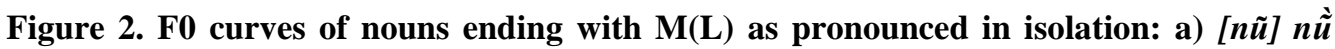

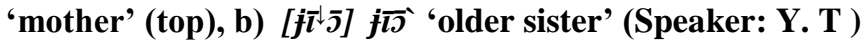

a. A monosyllabic word ending in $\mathrm{M}(\mathrm{L})$

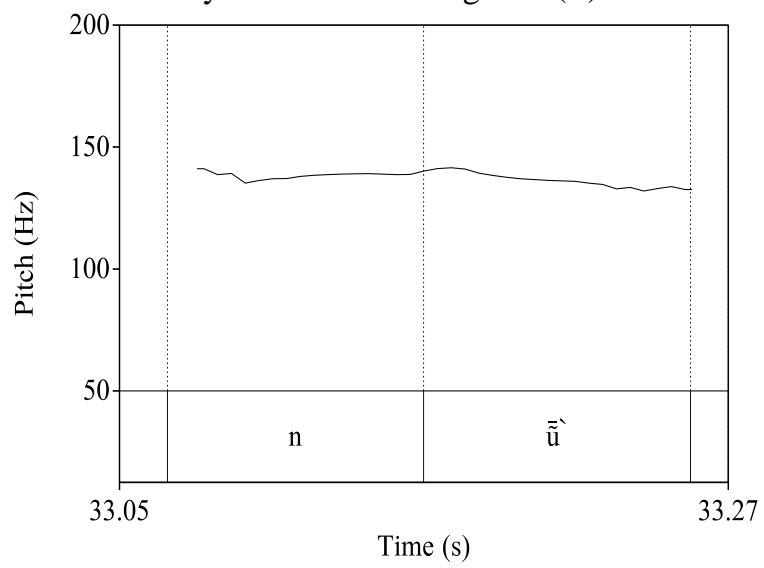

${ }^{2}$ This lowering is realized differently from a final $\mathrm{L}$ tone. The difference is clear when, for example, we compare $k \bar{e}:-r \bar{e}$ ' 'field' in isolation and $k \bar{e}: r \bar{e} k \dot{\tilde{u}}$ 'cut a field' with a final L linked tone (ex. 73). kùे is realized lower than $r \bar{e}$ of $k \bar{e}:-r \bar{e}$ in isolation. However, the difference is not always clear-cut between this intermediate realization (between a $\mathrm{M}$ and a $\mathrm{L}$ ) and a $\mathrm{L}$ in this position. This ambiguity is reflected by the variations in tonal annotations among authors (Katia Kamara, 1988, Traoré, 2020). 
b. A disyllabic word ending in $\mathrm{M}(\mathrm{L})$

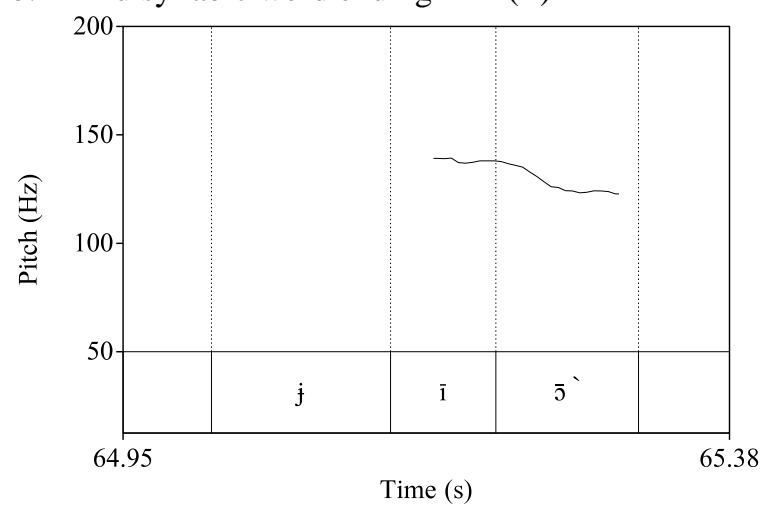

Floating $(\mathrm{H})$ tones also occur at the end of a set of $\mathrm{L}$ words, besides words with a plain $\mathrm{L}$, compare the examples in (2)a and $\mathrm{b}$.

(2) Nouns ending with $\mathrm{L}(\mathrm{H})$ or $\mathrm{L}$
a. $\quad \mathrm{L}(\mathrm{H})$

\begin{tabular}{|c|c|}
\hline àplè' & tòsò' \\
\hline 'ladle' & 'chili pepper' \\
\hline
\end{tabular}
b. L

$\begin{array}{lll}\text { pằ } & \text { dègè } & \text { nằdò?ò } \\ \text { 'lizard' } & \text { 'yard' } & \text { 'yam' }\end{array}$

As we saw for floating $(\mathrm{H})$ tones after $\mathrm{M}$ tones, these $(\mathrm{H})$ at the end of $\mathrm{L}$ words have two instantiations: they are involved in tonal rules (see Sections 2, 3 and 4) and, at the end of utterances, they modify the last tone $\mathrm{L}$ which is realized with a flat contour and tends to be raised (Figure 3).

Figure 3. F0 curves of a noun ending with $\mathrm{L}(\mathrm{H})$ as produced in isolation: [àplè ${ }^{\circ}$ àplè ' 'ladle' (Speaker: Y. T )

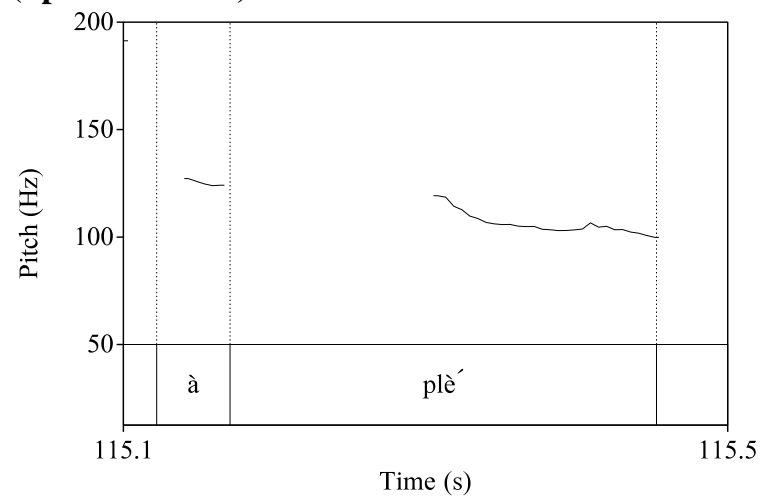

This flat contour contrasts with the falling contour of utterance-final L tones, which is the common contour of final L tones in African tone languages. 
Figure 4. Fo curve of a noun [nădò?ò] nădò?ò 'yam' with $L$ tones only as produced in isolation. Speaker Y. T.

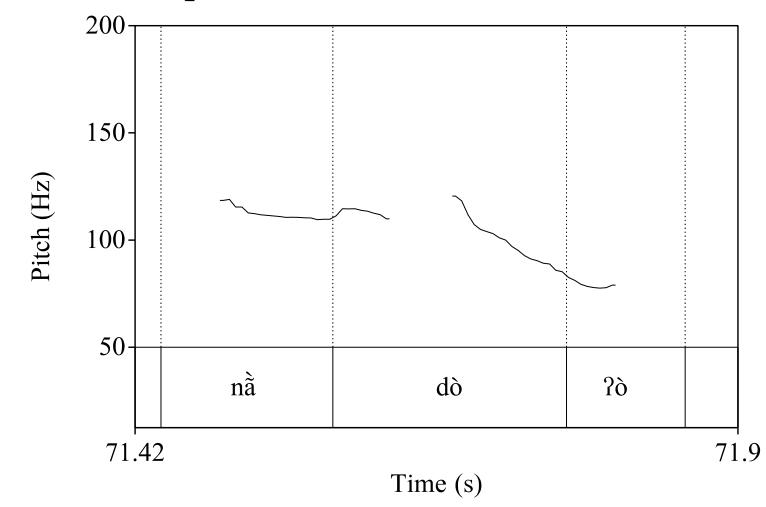

Non-falling realizations of a $\mathrm{L}$ tone when followed by a floating $(\mathrm{H})$ have been documented in many African languages (in Kenyang, Odden 1988, in Ngamambo, Asongwed \& Hyman 1976, in Mbam-Nkam, Hyman \& Tadadjeu 1976 in Kwakum, Njantcho Kouagang 2018 among many others). They are generally transcribed as $\mathrm{L}^{\circ}$. In a tonal geometry perspective, Hyman (1993) represents this type of non-falling $\mathrm{L}$ tone by a $\mathrm{H}$ register tone added to the $\mathrm{L}$ tone, as the realization of the final $\mathrm{L}$ tone and the realization of the floating $(\mathrm{H})$ tone are not sequential (there is no rising contour) but simultaneous. Due to data similarity, the same analysis can be carried over to Tagbana.

In Tagbana, the question of the sequentiality in the realization of the last fixed tones and the $(\mathrm{L}) /(\mathrm{H})$ floating tones at the end of an utterance does not only concern the $\mathrm{L}(\mathrm{H})$ patterns but also the other $\mathrm{T}(\mathrm{T})$ patterns. Besides a final $\mathrm{L} / \mathrm{L}^{\circ}$ contrast, there is also a seemingly parallel contrast between $\mathrm{M}$ (with a falling contour) and $\mathrm{M}^{\circ}$ (with a flat contour) ${ }^{3}$. However, the analogy is not perfect as, unlike with $\mathrm{L}$, both contours related to $\mathrm{M}$ involve a floating tone: the $\mathrm{M}$ with a final fall refers to a $\mathrm{M}(\mathrm{L})$ while the $\mathrm{M}^{\circ}$ with the flat contour is the realization of the $\mathrm{M}(\mathrm{H})$ pattern. In dissyllabic words in isolation, the $(\mathrm{L})$ is manifested by a lowering of the last $\mathrm{M}^{4}$ while the $(\mathrm{H})$ stays floating and is not expressed.

In Tagbana, there is no noun ending with a simple $M$ tone: in both cases, a final floating tone is involved. In other Senufo languages, the phonology of $M$ tones is complex as well, with a Ms (=M strong), Mw (=M weak) and MwL (=Mid Weak Low) posited in Supyire for example (Carlson 1994) and a historical 4 tone system hypothesized as a source of this complexity (Garber 1987). The absence of simple $M$ tone patterns, though rare, has also been noted in Tiefo, a Gur language spoken in Burkina Faso. 'There is no pure /M/ melody for noun stems' (Heath \& al. 2017. p18).

We note that, in Tagbana, floating $(\mathrm{L})$ at the end of words with final $\mathrm{H}$ seems very rare and even questionable. ${ }^{5}$

Spreading and replacement tonal rules are the main cues for floating tones, but they are also indicators of the associations between tones and syllables. These rules will be extensively

\footnotetext{
${ }^{3} \mathrm{M}^{\circ}$ : this notation is ours.

${ }^{4}$ In line with Hyman (1993), this lowering can be analyzed as the result of a simultaneity in the realization of the last $\mathrm{M}$ and of the final (L) which introduces a $\mathrm{L}$ register tone.

${ }^{5}$ We found no example with $\mathrm{H}(\mathrm{L})$ and only one potential example with $\mathrm{HH}(\mathrm{L})$ : jágá 'yesterday', realized with or without a slight fall and transcribed as jágà by Kanga-Eba. Being seemingly very rare, and maybe variants of HL realizations, these patterns will not be included in this study.
} 
studied in the following sections and they will show that in Tagbana, consecutive identical tones correspond to single tones associated to more than one syllable (see Sections 2 and 3). In the examples presented in this article, tones are transcribed on each vowel.

1.1.2 Lexical tone patterns. CV nouns, which are also roots as they do not have an overt class marker (see below for more detail about class markers), have one tone (3)a, b, or a linked tone plus a floating tone (3)c. The $M(L)$ is realized [mid] in isolation (see Figure 2a), the floating (L) being made visible by tone rules in various constructions (see Sections $2,3,4$ ).

(3) Lexical tones on monosyllabic nouns
a. $\mathbf{H}$ blá wré
'trousers' 'body'
b. $\quad \mathbf{L}$ nũ̀ pã̀
'ox' 'lizard'
$\begin{array}{lll}\text { c. } & \mathbf{M}(\mathbf{L}) \quad \begin{array}{l}\text { tō' } \\ \text { 'father' }\end{array} & \text { cō' } \\ & \text { 'wife' }\end{array}$

The small number of patterns is noticeable, particularly the absence of $\mathrm{M}(\mathrm{H})$, when compared with the patterns found in CVV (in 4.) or in disyllabic nouns (in 5.).

In CVV nouns (which are also equal to roots), when two vowels form a hiatus, the two adjacent syllables always share a single tone, see (4). It is not entirely clear whether these words are mono- or disyllabic: the first vowel is either [i] or [u], speaking for a glide. Moreover, when these words change their tone because of a tone sandhi rule or spreading, both vowels are affected.

(4) Lexical tones on nouns containing a hiatus CVV

\begin{tabular}{|c|c|c|c|}
\hline LL & $/ \mathrm{L} /$ & $\begin{array}{l}\text { pì̀ } \\
\text { 'child' }\end{array}$ & $\begin{array}{l}\text { kùò } \\
\text { 'salt' }\end{array}$ \\
\hline $\mathrm{HH}$ & $/ \mathrm{H} /$ & $\begin{array}{l}\text { jî̃á } \\
\text { 'grace' }\end{array}$ & $\begin{array}{l}\text { tíá } \\
\text { 'corn powder', }\end{array}$ \\
\hline $\mathrm{MM}(\mathrm{H})$ & $/ \mathbf{M}(\mathbf{H}) /$ & $\begin{array}{l}\text { jī̄o' } \\
\text { 'house' }\end{array}$ & $\begin{array}{l}\text { hĩ } \overline{\tilde{\varepsilon}}^{\prime} \\
\text { 'human being' }\end{array}$ \\
\hline $\mathrm{MM}(\mathrm{L})$ & $/ \mathbf{M}(\mathbf{L}) /$ & $\begin{array}{l}\text { sī̄̃' } \\
\text { 'bike' }\end{array}$ & $\begin{array}{l}\text { jī̄' } \\
\text { 'older sister' }\end{array}$ \\
\hline
\end{tabular}

In phonological forms, sequences of identical tones are represented by a single tone. This representation is supported by spreading rules affecting both tones (see 2.2.).

Nouns without class marker (= roots) can be longer, in which case they display a large diversity of tone combination, as exemplified in (5).

(5) Lexical tones in disyllabic nouns

\begin{tabular}{|c|c|c|c|}
\hline LL & $/ \mathrm{L} /$ & $\begin{array}{l}\text { dìsò } \\
\text { 'hunter' }\end{array}$ & $\begin{array}{l}\text { àtò } \\
\text { 'spoon' }\end{array}$ \\
\hline $\mathrm{HH}$ & /H/ & $\begin{array}{l}\text { sćbé } \\
\text { 'book' }\end{array}$ & $\begin{array}{l}\text { ákpá } \\
\text { 'rice' }\end{array}$ \\
\hline $\mathrm{LL}(\mathrm{H})$ & $/ \mathbf{L}(\mathbf{H}) /$ & $\begin{array}{l}\text { dã̀gò' } \\
\text { 'blanket' }\end{array}$ & $\begin{array}{l}\text { àplè' } \\
\text { 'ladle', }\end{array}$ \\
\hline $\mathrm{MM}(\mathrm{H} / \mathrm{L})$ & $/ \mathbf{M}(\mathbf{H} / \mathbf{L}) /$ & 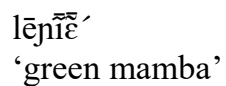 & $\begin{array}{l}\text { ālī } \bar{\varepsilon} \text { ' } \\
\text { 'ferment' }\end{array}$ \\
\hline
\end{tabular}




\begin{tabular}{|c|c|c|c|}
\hline $\mathrm{LM}(\mathrm{H})$ & $/ \mathbf{L M}(\mathbf{H}) /$ & $\begin{array}{l}\text { gàfā' } \\
\text { 'gazelle' }\end{array}$ & $\begin{array}{l}\text { àk } \bar{\varepsilon}^{\prime} \\
\text { 'traditional dance' }\end{array}$ \\
\hline $\mathrm{LH}$ & /LH/ & $\begin{array}{l}\text { bàbá } \\
\text { 'papa' }\end{array}$ & $\begin{array}{l}\text { kòló } \\
\text { 'well' }\end{array}$ \\
\hline HL /HL & $\mathrm{HL}(\mathrm{H}) / \mathbf{H L}(\mathbf{H}) /$ & $\begin{array}{l}\text { kátì } \\
\text { 'Sunday' }\end{array}$ & $\begin{array}{l}\text { kpákò' } \\
\text { 'coconut' }\end{array}$ \\
\hline
\end{tabular}

Disyllabic roots can be morphologically simple or complex. The minimality of many disyllabic roots is questionable as borrowing or compounding is diachronically a source of longer roots in Senufo languages (Garber, 1987), as it is in Mande or Gur/Mabia ${ }^{6}$ languages. ${ }^{7}$ The identification of the components is often only partially possible or not possible at all (see Vydrin, 2016, for Mande languages and the reconstruction of nominal roots).

1.2 Prosodic hierarchy of Tagbana. The traditional prosodic hierarchy is shown in (6) and it is first illustrated in (7) for English.

(6) Prosodic hierarchy

\begin{tabular}{|c|c|c|}
\hline t-phrase & intonation phrase & (corresponds roughly to a clause) \\
\hline$\Phi$-phrase & prosodic phrase & (corresponds roughly to a syntactic phrase) \\
\hline$\omega$-word & prosodic word & (corresponds roughly to a grammatical word) \\
\hline $\mathrm{F}$ & foot & (metrical unit: trochee, iamb...) \\
\hline$\sigma$ & syllable & (strings of segments: $\mathrm{CV}, \mathrm{CVC}, \ldots$ ) \\
\hline
\end{tabular}

(7)

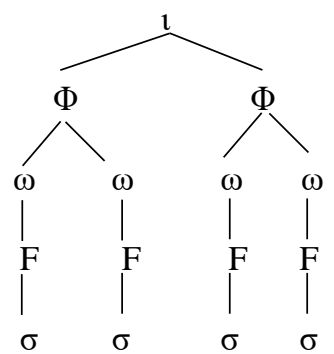

Big birds don't fly

In this article, we will use the recursive version of the prosodic hierarchy that has been proposed by Ito \& Mester and that allows every level of the hierarchy to be organized recursively, see (8).

\footnotetext{
${ }^{6}$ Mabia is a recently introduced alternative name for the Gur family (Bodomo \& al. 2018).

${ }^{7}$ Senufo languages, originally classified as Gur languages, display characteristics of both Gur languages and Mande languages. As Gur languages, they have class markers, also called class suffixes. In Gur languages, monosyllabicity of nominal roots is widespread (see Some 1982, for Dagara, Kabore 1981, for Moore, Ouoba 1982, for Gulmancema). In Mande languages, monosyllabic as well disyllabic roots are basic (Vydrin 2016). Tagbana does not have a large dictionary or diachronic studies to determine the simple roots. Consequently, the structure of many disyllabic roots can be ambiguous.
} 
(8) Recursive prosodic hierarchy (Ito \& Mester 2013)
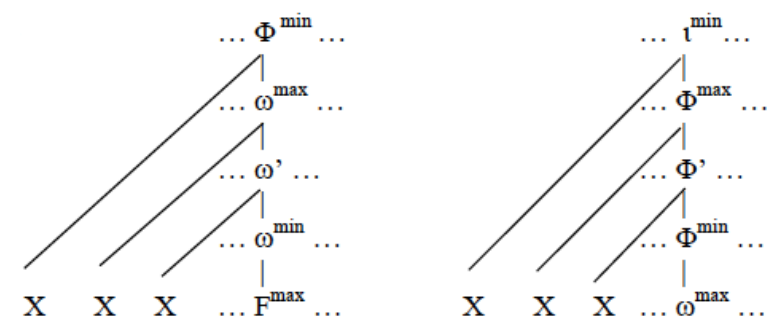

This alternative prosodic hierarchy allows for distinctions between different levels of the same category: a $\omega^{\min }$ can have different phonological correlates from a $\omega^{\max }$.

Maximal $\omega\left(\omega^{\max }\right)$ : $\omega$ not dominated by $\omega$.

Minimal $\omega\left(\omega^{\mathrm{min}}\right)$ : $\omega$ not dominating $\omega$.

Intermediate $\omega^{\prime}: \omega$ dominated by $\omega$ and dominating $\omega$.

We will show that the distribution of tones and the tonal sandhi effects in Tagbana lead us to assume a recursive structure for the prosodic domains. We will examine tones from the smaller prosodic constituents to the larger ones, thus first the minimal prosodic word, the intermediate prosodic word, the maximal prosodic word, the minimal prosodic phrase, the maximal prosodic phrase and the intonation phrase. There may be other prosodic domains, but we did not find any evidence for them at this point. Our conclusion is that in the prosodic hierarchy from the level of the prosodic word and up, a larger number of tonal processes take place in smaller constituents than in larger ones. In the Intonation Phrase, no tonal rules apply other than those occurring in the smaller prosodic domains.

The prosodic domains correspond to the following morpho-syntactic domains, as illustrated in (9).

(9) Prosodic domains

$\begin{array}{ll}\text { 1-phrase } & \text { Intonational Phrase } \\ \Phi^{\max } & \text { Prosodic Phrase Max } \\ \Phi^{\min } & \text { Prosodic Phrase Min } \\ \omega^{\max } & \text { Prosodic word Max } \\ \omega^{\prime} & \text { Prosodic word Intermediate } \\ \omega^{\min } & \text { Prosodic word Min }\end{array}$

Morpho-syntactic domains

(clause)

(nominal subject), (verb phrase), (adjunct)

(nominal object) (verb)

(noun+adjective compound), (noun+verb compound)

(noun+noun compound)

(noun+Class Marker), (noun)

This survey is preliminary and may need extensions when verbal, adverbial and adjectival constituents are considered as well.

\section{Prosodic Word}

The Prosodic Word $(\omega)$ is divided into three levels: a minimal $\omega^{\min }$ (Section 2.1), an intermediate $\omega$ ' (Section 2.2) and a maximal $\omega^{\max }$ (Section 2.3) that correspond to different morpho-syntactic categories.

2.1 Minimal Prosodic Word. From a morpho-syntactic point of view, a minimal prosodic word $\omega^{\text {min }}$ consists of an unaffixed lexical root or of a lexical root plus a class marker (CM). From a 
morphological perspective, all nouns consist of a category-less lexical root and a nominal CM, as shown in (10), see Traoré \& Féry (2018) for a morphological analysis. However, the CM can be overt or covert: the nouns in (3) to (5) have a covert CM. We call the configuration in (10) 'simplex noun' because it is the smallest nominal domain existing in the language.

(10)

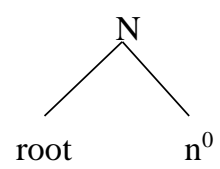

Most Tagbana nouns have an overt CM. CMs are specified for their consonant but not for their vowel and their tone. These class markers are: -lV (CM1a), - $n \mathrm{~V}$ (CM1b), -hV (CM1c), -lV (CM2c, CM3), -?VlV (CM4), -gV (CM5a), - pV (CM5b), -?V (CM5c), -rV (CM6), m/p-V (CM7), see Traoré (2020). Their vowel is a full copy of the last vowel of the lexical root. In Tagbana, as in Senufo and Gur languages generally, the bare nominal root occurs in some syntactic constructions, particularly in nominal and adjectival compounds. Thus, the tone of the root can be determined based on the tone of the bare form of the root as it appears in the first member of compounds. For further information on the constructions of nominal and adjectival compounds involving bare roots and on the tones of bare roots, we refer the reader to Section 3.

The tone of the $\mathrm{V}$ slot of the $\mathrm{CM}$ is specified depending upon the tone(s) of the root:

(1) if the root ends with $\mathrm{H}$ or L, this last L or $\mathrm{H}$ spreads on the V slot, see (11)a,b,

(2) if the root ends with $\mathrm{M}(\mathrm{L}), \mathrm{M}(\mathrm{H})$ or $\mathrm{L}(\mathrm{H})^{8}$, the linked tone, either $\mathrm{M}$ or $\mathrm{L}$, spreads on the $\mathrm{V}$ slot and the floating tone of the root occurs at the end of the noun, see (11)c,d,e.

The data in (11) illustrate these tonal processes on various class markers.

\begin{tabular}{|c|c|c|c|}
\hline \multicolumn{4}{|c|}{ Tones in nouns (lexical root $+\mathrm{CM}$ ) } \\
\hline a. & $/ \mathbf{L} /$ & dà:-1V & hũ்-mV \\
\hline & & dà:-là & hũ̀-mũ̀ \\
\hline & & yard-CM3 & oil-CM7 \\
\hline & & 'yard' & 'oil' \\
\hline \multirow[t]{4}{*}{$\mathrm{b}$} & $/ \mathbf{H} /$ & nวิ-nV & fá-?V \\
\hline & & กวิ์-ทว์ & fá-?á \\
\hline & & guinea-fowl-CM1 & cloud-CM5 \\
\hline & & 'guinea-fowl' & 'cloud' \\
\hline \multirow[t]{4}{*}{$\mathrm{c}$} & $/ \mathbf{M}(\mathbf{L}) /$ & $f \overline{\tilde{u}}-n V$ & kē:'-rV \\
\hline & & fü-n $\overline{\tilde{\tilde{u}}}$ & kē:-rēè \\
\hline & & hunger-CM5 & field-CM6 \\
\hline & & 'hunger' & 'wine' \\
\hline \multirow[t]{4}{*}{$\mathrm{d}$. } & $/ \mathbf{M}(\mathbf{H}) /$ & àjī̄o:'-lV & $t \overline{1}^{\prime}-? V$ \\
\hline & & $\bar{a} \bar{j} \overline{1} \bar{\partial}: 1 \bar{\nu}^{\prime}$ & $\mathrm{t} \overline{1}-? \overline{1}^{\prime}$ \\
\hline & & tumbler-CM3 & tree-CM5 \\
\hline & & 'tumbler' & 'tree' \\
\hline
\end{tabular}

\footnotetext{
${ }^{8}$ Diachronically, the floating tone of a root might originate from the tone of the Class Marker. This possible origin might explain why we have no root and consequently no noun ending with a linked $\mathrm{M}$ tone. The $(\mathrm{H})$ and (L) might come from the tone of the $\mathrm{CM}$, reinterpreted as part of the root tones.
} 


$\begin{array}{lll}\text { e. } \quad / \mathbf{L}(\mathbf{H}) \mathbf{f}^{9} & \text { hùò:'-lV } & \text { àblò'-?V } \\ & \text { hùò:lò' } & \text { àblò?ò' } \\ & \text { dishes-CM2 } & \text { peanut-CM5 } \\ & \text { 'dishes' } & \text { 'peanut' }\end{array}$

As mentioned previously, in Gur as in Senufo languages, roots are not abstract forms, but they are found in their bare state in compounding constructions. Their final floating tone can be retrieved by tonal rules (see 2.2. and 2.3.).

The noticeable point is that in noun formation, the floating tone of the root is not associated to the empty $\mathrm{V}$ of the suffix, that is to the available tone bearing unit on its right: the floating tone is aligned with the end of the word.

Some class markers, listed in (12), are fully specified with the front mid [+ATR] vowel [e]. These three CMs are plural ones. CMs of classes 2 and 4 also have alternative forms of the CM that behave like the other CMs in having an unspecified vowel slot.

$$
\text { -bēlē (CM2), -hélé (CM2), -gélé (CM4). }
$$

To sum up this section, a noun consisting of a lexical root plus a CM is prosodically a minimal prosodic word $\omega^{\mathrm{min}}$. The underspecified vowel slot of the CM is filled with a copy of the last linked vowel of the lexical root together with its tonal specification. ${ }^{10}$

\subsection{Intermediate prosodic word}

2.2.1 Noun + noun compounds. The next prosodic level is the intermediate prosodic word $\omega$ ' that consists of a noun + noun compound. It is conspicuous that two different structures are possible for this kind of compounds, that are illustrated in (13). In the left-hand illustration (13)a, both roots are joined together and form a stem. The unique CM is suffixed to this stem that acquires the class of the rightmost root, see examples in (14). In the righthand illustration (13)b, each root keeps its own $\mathrm{CM}$ in compounding, see examples in (15). In some cases, we find minimal pairs like those shown in (14) and (15). The former structure expresses an inalienable relationship whereas the latter one characterizes an alienable possession relation, as the paraphrases in parentheses indicate. Moreover in the first case, voicing of the initial obstruent of the second word takes place, but not in the second case, speaking for a tighter prosodic relationship in (13)a than in (13)b. Despite these differences between the two kinds of compounding, we still assume that they form the same prosodic domain, because their tonal behaviour is identical. More investigation is needed to fully understand these two structures.

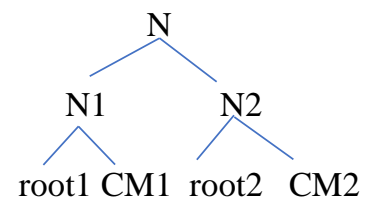

\footnotetext{
${ }^{9}$ Some nouns derived from LH dissyllabic verbs such as klò?ló 'fact of rolling' from klò?ó 'roll' does not seem to follow the same pattern. However, their formation is different and an anchored $\mathrm{H}$ tone on the second syllable could be posited.

${ }^{10}$ It must be noted that this vowel is often deleted in connected speech, see Traoré (2020) and Traoré \& Féry (2019) for vowel deletion.
} 


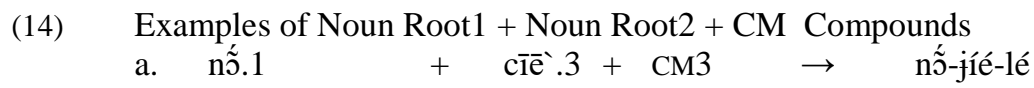 guinea fowl
foot
'guinea fowl's foot'
$\begin{array}{ll}\text { b. } & \text { hẽ́.3 } \\ \text { parrot }\end{array}$
$+\underset{\text { tree }}{\mathrm{t}^{\prime} .5}+\mathrm{CM} 5$
$\rightarrow \quad$ hẽ̃-dí-?í
(the animal is whole)
'parrot tree'
(parrots' favourite tree)

(15) Examples of Noun Root1-CM1 + Noun Root2-CM2 Compounds
a. nố-nố + ciē-lè
guinea fowl-CM5 foot-CM3
nõ̃-n-jíé-lé
'foot of guinea fowl'

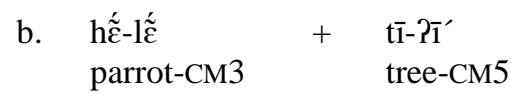
(as a piece of meat)
$\rightarrow \quad$ hẽ́-1-tí-?í
'parrot tree'
(there is a parrot right now)

Note that the last vowel of the first term of the compound is elided, in general the vowel of the CM.

2.2.2 Tonal sandhi rules triggered by nouns ending with linked $H$ or L. In both structures, tonal sandhi rules are triggered by the last tone of the first term of the compound (either a root or a root $+\mathrm{CM}$ ) and these rules affect the tone(s) of the second term. The sandhi rules are similar for both structures and examples of either structures will be given to illustrate this similarity (see (21) to (26) and (28) to (37)).

There are three types of tonal rules applying in this domain: the 'Mid Replacement rules' (RepM), the 'Raising L' (RaisL) and the 'Spreading L' (SprL).

RepM rules characterize the replacement of a $\mathrm{M}(\mathrm{L} / \mathrm{H})$ tone pattern by a preceding $\mathrm{L}$ or $\mathrm{H}$ tone. Sequences of $\mathrm{M}$ tones behave as a single tone, even though $\mathrm{M}$ can be distributed on several syllables. The result of RepM is that the whole string of $M$ tones with its floating (H/L) is replaced by $\mathrm{H}$ or $\mathrm{L}$. The effects of this rule can be schematized as follows:

\section{RepM}

a. $\sigma$
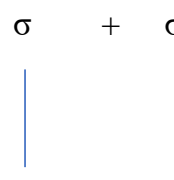

$\mathrm{H}$

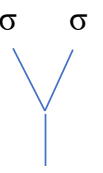

M (L/H)

$\mathrm{b}$

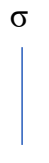

$\mathrm{L}$

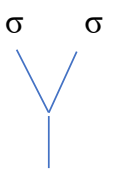

M (L/H)

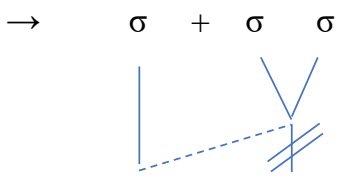

$\mathrm{H} \quad \mathrm{M}(\mathrm{L} / \mathrm{H})$

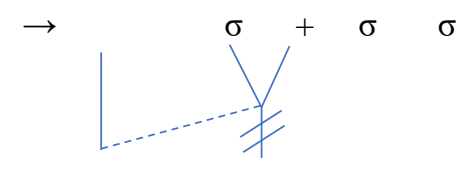

$\mathrm{L} \quad \mathrm{M}(\mathrm{L} / \mathrm{H})$

RaisL rule characterizes the raising of $\mathrm{L}$ after $\mathrm{H}$ to $\mathrm{M}(\mathrm{H})$. A string of $\mathrm{L}$ also behaves as a single tone. This raising is triggered by the spreading of $\mathrm{H}$ but the $\mathrm{L}$ tone does not undergo a 
replacement as $\mathrm{M}(\mathrm{L} / \mathrm{H})$ does in RepM (16). It combines with $\mathrm{H}$ resulting in $\mathrm{M}(\mathrm{H})$, as represented below ${ }^{11}$.

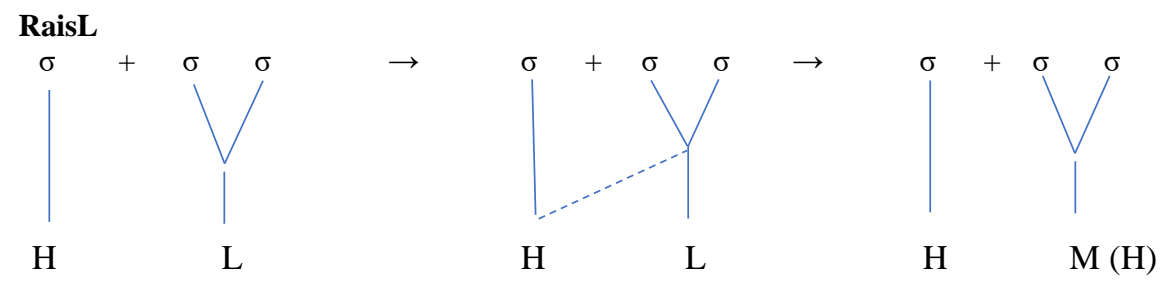

SprL rule characterizes the spreading of $L$ on a following $H$. This rule affects only one syllable at a time, see Table (19).

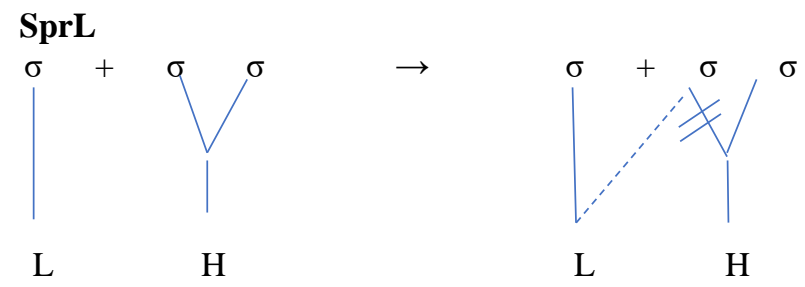

In Table (19), all combinations of $\mathrm{H}$ or $\mathrm{L}$ ending a first term and the tones of a second term $^{12}$ are reviewed. The results of the tonal sandhi rules appear in the last columns. RepM, RaisL and SprL are involved in $\omega^{\prime}$. When $/ \mathrm{H} /$ spreads into $/ \mathrm{L} / \mathrm{L} / \mathrm{L} /$ is raised to $/ \mathrm{M}(\mathrm{H}) /$, see (19)b, and when /H/ spreads into $/ \mathrm{M}(\mathrm{H} / \mathrm{L}) /, / \mathrm{M}(\mathrm{H} / \mathrm{L}) /$ is replaced by $/ \mathrm{H} /$, see (19)c. When /L/ spreads to $/ \mathrm{H} /$, the result is a lowering to /L/ limited to the first syllable, see (19)e; when /L/ spreads to /M (H/L)/, /M(H/L)/ is globally replaced, see (19)f. No change occurs when identical tones are involved, see (19)a-d.

(19) Tonal sandhi rules triggered by nouns ending with $\mathrm{H}$ or $\mathrm{L}$

\begin{tabular}{lllll}
\multicolumn{2}{l}{ Last tone, $1^{\text {st }}$ term } & Tones, $2^{\text {nd }}$ term & Tones of compound & Tonal rules \\
a. $-\mathrm{H}$ & $\mathrm{HH} / \mathbf{H} /$ & $-\mathrm{H}+\mathrm{HH} /-\mathbf{H}+\mathbf{H} /$ & No change \\
b. $-\mathrm{H}$ & $\mathrm{LL} / \mathbf{L} /$ & $-\mathrm{H}+\mathrm{MM}(\mathrm{H}) /-\mathbf{H}+\mathbf{M}(\mathbf{H}) /$ & RaisL \\
c. & $-\mathrm{H}$ & $\mathrm{MM}(\mathrm{H} / \mathrm{L}) / \mathbf{M}(\mathbf{H} / \mathbf{L}) /$ & $-\mathrm{H}+\mathrm{HH} /-\mathbf{H}+\mathbf{H} /$ & RepM \\
d. & $-\mathrm{L}$ & $\mathrm{LL} / \mathbf{L} /$ & $-\mathrm{L}+\mathrm{LL} /-\mathbf{L}+\mathrm{L} /$ & No change \\
e. & $-\mathrm{L}$ & $\mathrm{HH} / \mathrm{H} /$ & $-\mathrm{L}+\mathrm{LH} / \mathbf{L}+\mathbf{L H} /$ & SprL \\
f. & $-\mathrm{L}$ & $\mathrm{MM}(\mathrm{H} / \mathrm{L}) / \mathbf{M}(\mathbf{H} / \mathbf{L}) /$ & $-\mathrm{L}+\mathrm{LL} /-\mathbf{L}+\mathbf{L} /$ & RepM
\end{tabular}

\footnotetext{
${ }^{11}$ As in simple nouns ending with $\mathrm{M}(\mathrm{H})$, the floating $(\mathrm{H})$ is not realized in words in isolation (see 1.1.1.) but is active in spreading rules. A simple $\mathrm{M}$ could have been expected as the result of RaisL but in Tagbana, there is no simple $\mathrm{M}$ at the end of a noun. $\mathrm{M}(\mathrm{H})$ is a well-formed pattern at the end of a noun and functions as the raised counterpart of the L pattern. Thus, the L tones of hò-lj 'ustensile' which are raised to $\mathrm{M}(\mathrm{H})$ in the compound

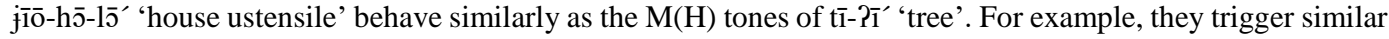
effects on a L tone of an infinitive such as cò 'to catch': jī̄o-hō-l-có 'to catch a house ustensil', tî̀-Pî̀ có 'to catch a tree'.

${ }^{12}$ The second term consists of a Nominal Root and a Class Marker. It has at least two syllables, except when there is no 'overt' Class Markers (see Traore 2020). Within the scope of this study, for the second term, we focus on disyllabic forms (Root $+\mathrm{CM}$ ) that quite generally display two identical linked tones, the second tone resulting from a spreading of the root tone (see Section 2.1). Remember that all M tone nouns have either a (L) floating tone or a $(\mathrm{H})$ floating tone. Further investigation would be needed to include longer roots which will introduce more complex patterns.
} 
Two comments on (19)b-c: First, RaisL triggers the raising of LL to $M M(H)$ in (19)b, involving not only the $\mathrm{M}$ tones but also the floating $(\mathrm{H})$. This clearly signals that the pattern $\mathrm{MM}(\mathrm{H})$ behaves as a single melodic unit. The whole /L/ noun is raised to $/ \mathrm{M}(\mathrm{H}) /$ and RaiseL applies to both syllables.

This type of raising is not an independent process, rather it only occurs with RepM. RepM suppresses the $\mathbf{M}$ tones of the second term and derived $\mathbf{M}$ tones emerges when RaiseL applies.

The combination of the RepM, RaiseL and SprL rules induce a 'chain shift', as shown in (20): the tones of the $2^{\text {nd }}$ term, more precisely of its first syllable, are modified as follows:

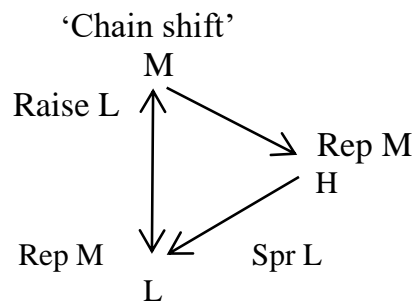

Turning to examples, let us start with the effects of H, illustrated in (21), (22) and (23), after which we continue with the other cases of Table (19).

a) $-\mathrm{H}+\mathrm{HH} \rightarrow-\mathrm{H}+\mathrm{HH}$

No rule is active and no change occurs. No downstep separates the Hs in contact.

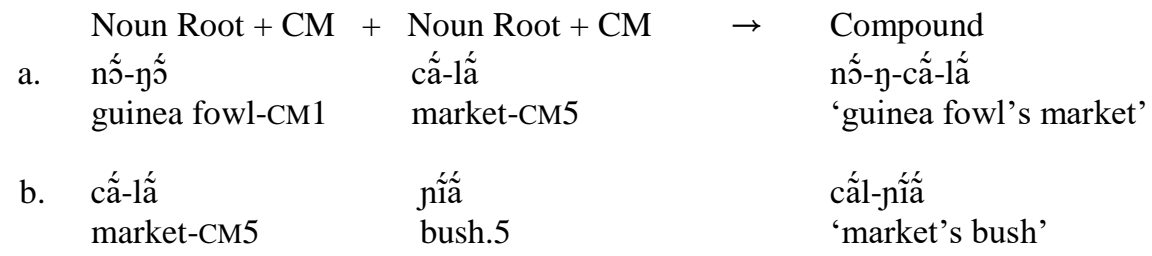

b) $\quad-\mathrm{H}+\mathrm{LL} \rightarrow-\mathrm{H}+\mathrm{MM}(\mathrm{H})$

$\mathrm{H}$ spreads on the $\mathrm{L}$ tone(s) which are raised to $\mathrm{M}$, more precisely to the $\mathrm{M}(\mathrm{H})$ pattern. This case reveals particularly clearly that the $\mathrm{MM}(\mathrm{H})$ pattern forms a single tone unit, globally replacing L tone(s).

$$
\begin{aligned}
& \text { Noun Root }+\mathrm{CM}+\text { Noun Root }+\mathrm{CM} \rightarrow \text { Compound } \\
& \text { a. nố-ñ̃ } \quad \text { kà-?à nố-n-kā-?à' } \\
& \text { guinea fowl-CM1 village-CM5 'guinea fowl's village' } \\
& \begin{array}{lll}
\text { b. cã́-lấ } & \begin{array}{l}
\text { kà-Pà } \\
\text { village-CM5 }
\end{array} & \begin{array}{l}
\text { cấ-gā-Pā' } \\
\text { 'market-CM5 }
\end{array} \\
\text { 'market's village' }
\end{array} \\
& \text { c) }-\mathrm{H}+\mathrm{MM}(\mathrm{H} / \mathrm{L}) \rightarrow-\mathrm{H}+\mathrm{HH}
\end{aligned}
$$

The examples in (23) illustrate the global replacement of $\mathrm{MM}(\mathrm{H})$ by $\mathrm{HH}$, affecting the whole sequence of $\mathrm{M}$ tones, as well as the final floating tone. 

a. nวิ-ทว์
guinea fowl-CM1
lā:-lā' ${ }^{\prime}$
belly-CM3
$\rightarrow$ Compound
nṍ-lá:lá
'guinea fowl's belly'
b. jî̃ấ
bush.5
tīā-lā'
pig-CM1
jĩ̃â-tíá-lá
'warthog'
mouse-CM1
mouse
c. hó-ló
kē:-rē'
field-CM6
field
hó-ké:-ré
mouse-field-CM6
'field of mouse'
d) $-\mathrm{L}+\mathrm{LL} \rightarrow-\mathrm{L}+\mathrm{LL}$

No change occurs when identical tones get in contact, see (24).
Noun Root $+\mathrm{CM}+$ Noun Root $+\mathrm{CM} \rightarrow$ Compound
a. kà-?à
drè-?è
shirt-CM5
kà?-drè-?è
village-CM5
kà-?à
b. hò-lò
ustensil-CM1
village-CM5
'village's shirt'
e) $-\mathrm{L}+\mathrm{HH} \rightarrow-\mathrm{L}+\mathrm{LH}$

The examples in (25) show that spreading of L onto $\mathrm{HH}$ only affects the first syllable of the second word.
f) $-\mathrm{L}+\mathrm{MM}(\mathrm{H} / \mathrm{L}) \rightarrow-\mathrm{L}+\mathrm{LL}$
kà-?-cã̀-lã́
'village's market'
dàl-noั̀-nวิ
'guinea fowl of the yard'

Examples in (26) illustrate the replacement of $/ \mathrm{M}(\mathrm{H} / \mathrm{L}) /$ by $/ \mathrm{L} /$. In this case, spreading affects the whole $\mathrm{MM}(\mathrm{H} / \mathrm{L})$ patterns involving both the linked $\mathrm{M}$ tone and the floating tone.
Noun Root $+\mathrm{CM}+$ Noun Root $+\mathrm{CM} \rightarrow$ Compound
a. kà-?à
village-CM5
$\mathrm{t} \overline{\mathrm{i}}-\mathrm{P} \overline{\mathrm{i}}^{\prime}$
tree-CM5
kà-?-tì-?ì
'village's tree
b. kà-?à
village-CM5
kē:rē
field-CM6
kà-?-kè:rè
'village's field'

2.2.3 Tonal sandhi rules by nouns with floating tones. Table (27) illustrates the effects of the tonal sandhi rules by nouns with floating tones. In this case, the final tones of the first term can be $\mathrm{M}(\mathrm{H})$, $\mathrm{L}(\mathrm{H})$ or $\mathrm{M}(\mathrm{L})$, as explained in Section 2.2.2. As was the case in nouns ending with $\mathrm{H}$ and $\mathrm{L}$, RepM, RaisL and SprL are active here as well. 
(27) Tonal sandhi rules by nouns with floating tones

\begin{tabular}{|c|c|c|c|c|c|}
\hline Last tones, $1^{\text {st }}$ term & Tone(s), $2^{\text {n }}$ & derm & Tones of comp & ound & Tonal rules \\
\hline$-\mathrm{M}(\mathrm{H})$ & $\mathrm{L} \mathrm{L}$ & $/ \mathrm{L} /$ & $-\mathrm{M}+\mathrm{M} M(\mathrm{H})$ & $/-\mathbf{M}+\mathbf{M}(\mathbf{H}) /$ & RaisL \\
\hline$-\mathrm{M}(\mathrm{H})$ & M M (H/L) & $/ \mathbf{M}(\mathbf{H} / \mathbf{L}) /$ & $-\mathrm{M}+\mathrm{H} \mathrm{H}$ & /-M+H/ & RepM \\
\hline$-\mathrm{M}(\mathrm{H})$ & $\mathrm{HH}$ & /H/ & $-\mathrm{M}+\mathrm{H} \mathrm{H}$ & /-M+H/ & No change \\
\hline$-\mathrm{L}(\mathrm{H})$ & L L & $/ \mathrm{L} /$ & $-\mathrm{L}+\mathrm{MM}(\mathrm{H})$ & $/-\mathbf{L}+\mathbf{M}(\mathbf{H}) /$ & RaisL \\
\hline$-\mathrm{L}(\mathrm{H})$ & $\mathrm{MM}(\mathrm{H} / \mathrm{L})$ & $/ \mathbf{M}(\mathbf{H} / \mathbf{L}) /$ & $-\mathrm{L}+\mathrm{HH}$ & $/-\mathbf{L}+\mathbf{H} /$ & RepM \\
\hline$-\mathrm{L}(\mathrm{H})$ & $\mathrm{HH}$ & $/ \mathbf{H} /$ & $-\mathrm{L}+\mathrm{HH}$ & $/-\mathbf{L}+\mathbf{H} /$ & No change \\
\hline$-\mathrm{M}(\mathrm{L})$ & $\mathrm{HH}$ & /H/ & $-\mathrm{M}+\mathrm{LH}$ & /-M+LH/ & SprL \\
\hline$-\mathrm{M}(\mathrm{L})$ & $\mathrm{MM}(\mathrm{H})$ & $/ \mathbf{M}(\mathbf{H}) /$ & $-\mathrm{M}+\mathrm{LL}$ & $/-\mathbf{M}+\mathbf{L} /$ & RepM \\
\hline$-\mathrm{M}(\mathrm{L})$ & $\mathrm{MM}(\mathrm{L})$ & $/ \mathbf{M}(\mathbf{L}) /$ & $-\mathrm{M}+\mathrm{MM}(\mathrm{L})$ & $/-\mathbf{M}+\mathbf{M}(\mathbf{L}) /$ & No change \\
\hline$-\mathrm{M}(\mathrm{L})$ & LL & $/ \mathrm{L} /$ & $-\mathrm{M}+\mathrm{LL}$ & /-M+L/ & No change \\
\hline
\end{tabular}

In this case, the floating tones are the triggers. The outputs are similar to the ones we saw for the nouns ending with linked $\mathrm{H}$ or $\mathrm{L}$ in Table (19) except in one case: the sequence $\mathrm{M}(\mathrm{L})+\mathrm{MM}(\mathrm{L})$ resulting in $\mathrm{MM}(\mathrm{L})$ and not in MLL, see (27)i. ${ }^{13}$ Note that this exception is consistently observed in similar conditions (see (48)g for another occurrence).

Let's turn to the examples, starting with the spreading of floating $(\mathrm{H})$ tone. In the same way as for Table (19), all cases of Table (27) are illustrated in turn.

$$
\text { a) }-\mathrm{M}(\mathrm{H})+\mathrm{LL} \rightarrow-\mathrm{M}+\mathrm{MM}(\mathrm{H})
$$

\begin{tabular}{|c|c|c|c|c|}
\hline a. & $\begin{array}{l}\text { Noun Root }+\mathrm{CM}+ \\
\dot{\mathrm{j}} \overline{\mathrm{O}}^{\prime} \\
\text { house. } 5\end{array}$ & $\begin{array}{l}\text { Noun Root + CM } \\
\text { hò-lò } \\
\text { ustensil-CM1 }\end{array}$ & $\rightarrow$ & 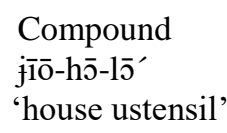 \\
\hline b. & $\begin{array}{l}\mathrm{t} \overline{\mathbf{1}}-\mathrm{P} \overline{\mathbf{1}}^{\prime} \\
\text { tree-CM5 }\end{array}$ & $\begin{array}{l}\text { àp-lè' } \\
\text { ladle- CM3 }\end{array}$ & & $\begin{array}{l}\text { tî̀-āp-le' } \\
\text { 'tree ladle' }\end{array}$ \\
\hline & $-\mathrm{M}(\mathrm{H})+\mathrm{MM}(\mathrm{H} / \mathrm{L})$ & $-\mathrm{M}+\mathrm{HH}$ & & \\
\hline
\end{tabular}

\begin{tabular}{|c|c|c|c|c|}
\hline a. & $\begin{array}{l}\text { Noun Root + CM + } \\
\text { tīā-lā' } \\
\text { pig-CM1 }\end{array}$ & $\begin{array}{l}\text { Noun Root + CM } \\
\text { kē:-rē } \\
\text { field-CM6 }\end{array}$ & $\rightarrow$ & $\begin{array}{l}\text { Compound } \\
\text { tīā-l-ké:ré } \\
\text { 'field of pig' }\end{array}$ \\
\hline b. & $\begin{array}{l}\text { tī-P' } \overline{1}^{\prime} \\
\text { tree-CM5 }\end{array}$ & $\begin{array}{l}\text { jū̃-mũ̃' } \\
\text { water-CM7 }\end{array}$ & & $\begin{array}{l}\text { tī?-nû́-mû́ } \\
\text { 'tree water' }\end{array}$ \\
\hline & $\rightarrow-\mathrm{M}$ & $\mathrm{IH}$ & & \\
\hline
\end{tabular}

\begin{tabular}{|c|c|c|c|}
\hline $\begin{array}{l}\text { Noun Root + CM } \\
\text { tīā-lā' } \\
\text { pig-CM1 }\end{array}$ & $\begin{array}{l}+ \text { Noun Root }+ \text { CM } \\
\text { kúmû́ } \\
\quad \text { funeral-CM1 }\end{array}$ & $\rightarrow$ & $\begin{array}{l}\text { Compound } \\
\text { tīāl-kúmũ } \\
\text { 'death of pigs' }\end{array}$ \\
\hline $\begin{array}{l}\text { tī-?ī' } \\
\text { tree-CM5 }\end{array}$ & $\begin{array}{l}\text { cấ-lấ } \\
\text { market-CM5 }\end{array}$ & & $\begin{array}{l}\text { tīl-cã́-lã́ } \\
\text { 'tree market' }\end{array}$ \\
\hline
\end{tabular}

\footnotetext{
${ }^{13}$ It is not straightforward to account for the fact that the (L) does not trigger the same effect as the linked tones, only in this case. We note that the non-application of RepM avoids the confusion of the $\mathrm{MM}(\mathrm{H})$ and $\mathrm{MM}(\mathrm{L})$ in the resulting compound.
} 
d) $\quad-\mathrm{L}(\mathrm{H})+\mathrm{LL} \rightarrow-\mathrm{L}+\mathrm{MM}(\mathrm{H})$
Noun Root $+\mathrm{CM}+$ Noun Root $+\mathrm{CM}$
a. àplè'
krò-?’̀
ladle. 3
back-CM5
àplè-krō-? '̄'
'ladle's back'
b. àtò'
kà-?à
spoon. 3
village-CM5
àtò-kā-?ā'
'spoon's village'
e) $-\mathrm{L}(\mathrm{H})+\mathrm{MM}(\mathrm{H} / \mathrm{L}) \rightarrow-\mathrm{L}+\mathrm{HH}$

(32)
$\begin{array}{ll}\text { a. } & \text { àplè' } \\ & \text { ladle. } 3\end{array}$
Noun Root $+\mathrm{CM}+$
Noun Root $+\mathrm{CM}$
$\rightarrow \quad$ Compound
àplè-tí-?í
'ladle's tree'
tree-CM5
b. bàgrà-?à'
hoe-CM5
$\mathrm{t} \overline{\mathrm{i}}-\mathrm{P} \overline{\mathrm{i}}^{\prime}$
tree-CM5
bàgrà?-tí-?í
'hoe's handle'
f) $-\mathrm{L}(\mathrm{H})+\mathrm{HH} \rightarrow-\mathrm{L}+\mathrm{HH}$

(33)
Noun Root $+\mathrm{CM}+$
a. bàgrà-?à'
hoe-CM5
Noun Root + CM
$\rightarrow$
Compound
bàgrà?-hú-?ú
'hoe's thorn'
b. àplè'
ladle. 3 thorn-CM5
àplè-níá
'ladle's bush'
g) $-\mathrm{M}(\mathrm{L})+\mathrm{HH} \rightarrow-\mathrm{M}+\mathrm{LH}$
jiã́. 5
'bush'

(34)
Noun Root $+\mathrm{CM}+$ Noun Root $+\mathrm{CM}$
$\rightarrow \quad$ Compound
a. lō-?ō'
mango-CM5
lō-fà-?á
'cloud of mango'
b. kē:-rē'
field-CM6
fá-Pá
cloud-CM5
kē:r-cã̀lá
'field market'
cấ-lã
market-CM5

h) $-\mathrm{M}(\mathrm{L})+\mathrm{MM}(\mathrm{H}) \rightarrow-\mathrm{M}+\mathrm{LL}$
Noun Root + CM + Noun Root + CM
a. hō-lō'

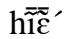
human being-CM1
$\rightarrow \quad$ Compound
elephant-CM1
hō-hĩ̀̃
'elephant owner'
$\begin{array}{ll}\text { b. } & \text { lō-?ō' } \\ \text { mango-CM5 }\end{array}$
$\mathrm{t} \overline{\mathrm{i}}-\mathrm{P} \overline{\mathrm{i}}^{\prime}$
tree-CM5
lō-dì-?ì.
'mango tree'
i) $\quad-\mathrm{M}(\mathrm{L})+\mathrm{MM}(\mathrm{L}) \rightarrow-\mathrm{M}+\mathrm{MM}(\mathrm{L})$
Noun Root + CM
a. 10̄-?ō'
Noun Root + CM
Compound
mango-CM5
kē:-rē'
lō-gē:rē'
'mango field' 

b. hō-lō’
elephant-CM1
lā-mā'
hō-lā-mā’
interior $-\mathrm{CM} 7$
'elephant's interior'
j) $\quad-\mathrm{M}(\mathrm{L})+\mathrm{LL} \rightarrow-\mathrm{M}+\mathrm{LL}$

\begin{tabular}{|c|c|c|c|}
\hline $\begin{array}{l}\text { Noun Root + CM + } \\
\text { hō-lō' } \\
\text { elephant-CM1 }\end{array}$ & $\begin{array}{l}\text { Noun Root + CM } \\
\text { kà-?à } \\
\text { village-CM5 }\end{array}$ & $\rightarrow$ & $\begin{array}{l}\text { Compound } \\
\text { hō-gà-?à } \\
\text { 'elephant's village' }\end{array}$ \\
\hline $\begin{array}{l}\text { lō-?ō' } \\
\text { mango-CM5 }\end{array}$ & $\begin{array}{l}\text { krò-?’̀ } \\
\text { car-CM5 }\end{array}$ & & $\begin{array}{l}\text { lō-krò-?̀̀ } \\
\text { 'mango's car' }\end{array}$ \\
\hline
\end{tabular}

In sum, the $\mathrm{N}+\mathrm{N}$ compounding is an intermediate prosodic word $\omega^{\prime}$, sandwiched between $\omega^{\min }$ and $\omega^{\max }$, illustrated in the next subsection. This prosodic constituent is characterized by the interplay of three sets of rules: M replacement rules (RepM), Raise L (RaisL) and Spread L (SprL). The rules are basically the same when triggered by a linked tone or by a floating tone-with the exception of $(\mathrm{L})$ in $-\mathrm{M}(\mathrm{L})+\mathrm{M}(\mathrm{L})$.

2.3 Maximal Prosodic Word. The next prosodic level is the Maximal Prosodic Word $\omega^{\max }$ : a lexical root + an attributive adjective $+\mathrm{CM}$ of the class of the noun. ${ }^{14}$

When pronounced alone, adjectival roots take a default CM5 [-PV], i.e. a category-defining morpheme (see Traoré 2020 for more). In this case, adjectives are nominal, see (38), and examples in (39).

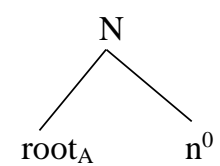

Adjectives with default [-?V] CM5
a. LL/L/
fì-?ì

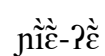
'white-CM5'
'red-CM5'
b. $\mathrm{HH} / \mathrm{H} /$
krú-?ú
sí-nĩ́
'second-CM5'
'straight-CM5'
c. $\quad \mathrm{MM}(\mathrm{L}) / \mathrm{M}(\mathrm{L}) / \quad \begin{aligned} & \mathrm{kmã}-? \overline{\tilde{a}} \\ & \text { 'good-CM5 }\end{aligned}$,
wนิ๊̄̄ว̄’
'black-CM5'

Noun + adjective compounds have the structure shown in (40). The lexical root and the adjectival root form a stem together, see Traoré (2020). The compound ends with a CM of the class of the nominal root.

\footnotetext{
${ }^{14} \mathrm{~A}$ lexical root + a verbal root $+\mathrm{CM}$ seems to form a $\omega^{\max }$, as well. Here, we ignore these compounds and focus on the noun + adjective compounds.
} 
(40)

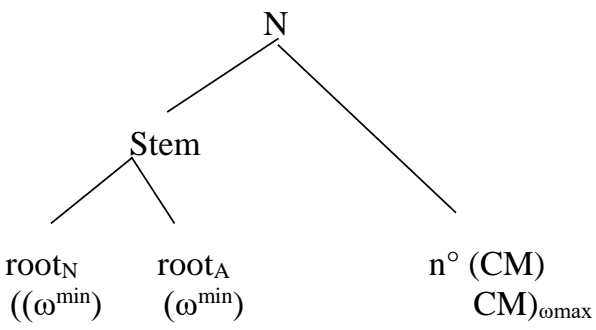

The class of the adjectival compound is determined by the class of the nominal root. A class marker can have its own vowel and tones as for instance in -bélé (CM2) but more often, it is only specified for its consonant and acquires the quality of its unspecified V slot by vowel harmony, see Section 2.1. In this case, the V slot of the CM receives a tonal specification by the same processes as those operating in Minimal Prosodic Words.

2.3.1 Mid Replacement Rules (RepM) with nominal roots ending in H or L. The Maximal Prosodic Word just illustrated is host to the RepM 'Mid Replacement Rules' that were introduced in Section 2.2. Anchored $\mathrm{H}$ and $\mathrm{L}$ tones on the final syllable of the noun spread on the following $\mathrm{M}$ tone of the adjective and replace it. SprL is active in triggering the following L but RaisL is inactive in this domain. The formation of M-based contours such as $\mathrm{MM}(\mathrm{H})$ on the second part of the compound is avoided.

Adjectives form a very small lexical class and we did not find adjectival forms ending with the $\mathrm{M}(\mathrm{H})$ pattern.

(41) Tonal sandhi rules triggered by noun roots ending with $\mathrm{H}$ and $\mathrm{L}$

\begin{tabular}{|c|c|c|c|}
\hline $\begin{array}{l}\text { Last tone, } \\
\text { Noun root }\end{array}$ & $\begin{array}{l}\text { Tone(s), } \\
\text { Adj. Root + C }\end{array}$ & $\begin{array}{l}\text { Tones of } \\
\text { Adjectival compounds }\end{array}$ & Tonal rules \\
\hline$-\mathrm{H}$ & $\mathrm{MM}(\mathrm{L}) / \mathbf{M}(\mathbf{L}) /$ & $-\mathrm{H}+\mathrm{HH} \quad /-\mathbf{H}+\mathbf{H} /$ & RepM \\
\hline$-\mathrm{L}$ & $\mathrm{MM}(\mathrm{L}) / \mathbf{M}(\mathbf{L}) /$ & $-\mathrm{L}+\mathrm{LL} \quad /-\mathbf{L}+\mathbf{L} /$ & RepM \\
\hline$-\mathrm{H}$ & $\mathrm{HH}$ & $-\mathrm{H}+\mathrm{HH} \quad /-\mathbf{H}+\mathbf{H} /$ & No change \\
\hline$-\mathrm{H}$ & /L/ & $-\mathrm{H}+\mathrm{LL}$ & No change \\
\hline$-\mathrm{L}$ & LL & $-\mathrm{L}+\mathrm{LL}$ & No change \\
\hline$-\mathrm{L}$ & $\mathrm{HH}$ & $/-\mathbf{L}+\mathbf{L H} /$ & SprL \\
\hline
\end{tabular}

The examples (42) to (47) illustrate all cases of Table (41). Note that the second term (adjective root $+\mathrm{CM}$ ) always has at least two syllables, because the $\mathrm{CM}$ is always overt in such a compound.

\section{a) $-\mathrm{H}+\mathrm{MM}(\mathrm{L}) \rightarrow-\mathrm{H}+\mathrm{HH}$}

The examples (42) show that when $/ \mathrm{H} /$ spreads on $/ \mathrm{M}(\mathrm{L}) /, / \mathrm{M}(\mathrm{L})$ is replaced as a single tone. In the adjective $t \bar{\imath} c \bar{a} P \bar{a} g \bar{a}$ ' 'quick', all three syllables are affected by $\mathrm{H}$ spreading into $\mathrm{M}$, and floating $(\mathrm{L})$ or $(\mathrm{H})$ is erased.
Noun Root +
a. cá-
lake.1
fõ̀- CM1 cá-fó-nó
new
'new lake'
Adj. Root $+\mathrm{CM} \rightarrow$ Compound
b. noิ́-
tīcā?ā'-
CM1
nố-tícá?á-gá
guinea fowl.1
quick
'quick guinea fowl' 
b) $-\mathrm{L}+\mathrm{MM}(\mathrm{L}) \rightarrow-\mathrm{L}+\mathrm{LL}$

When /L/ spreads on $/ \mathrm{M}(\mathrm{L}) /, / \mathrm{M}(\mathrm{L}) /$ is replaced as a single tone as well, see (43)a-b.
Noun Root +
Adj. Root
$\mathrm{CM}$
fo-
CM1
$\rightarrow$ Compound
nuิ̀-fวั-ทวั
ox.1
new
'new ox'
b. krò-
rubber.6
kmã̃-
CM6
krò-kmã:-rã̀
good
'good rubber'
c) $-\mathrm{H}+\mathrm{HH} \rightarrow-\mathrm{H}+\mathrm{HH}$

No change is taking place.

(44)
a. hó-
Noun Root +
Adj. Root +
CM
Compound
mouse. 1
sí-
straight
hó-sĩ̀-nĩ
'straight mouse'
b. nṍ-
guinea fowl.1
sí-
straight
CM1
nṍ-sĩ́ ฤĩ́
'straight guinea
fowl'

d) $-\mathrm{H}+\mathrm{LL} \rightarrow-\mathrm{H}+\mathrm{LL}$

RaisL is not active here and no change is taking place.
wré-
body. 6
Noun Root +
Adj. Root $+\mathrm{CM}$
CM
CM6
$\rightarrow$ Compound
'white body'
wré-fî:-rì
white
b. blá-
trousers. 1
fì-
white
CM1 $\rightarrow$ blá-fì-hù
'white trousers'

e) $-\mathrm{L}+\mathrm{LL} \rightarrow-\mathrm{L}+\mathrm{L} \mathbf{L}$

In this configuration as well, no change is taking place.
a. nù-
Noun Root +
Adj. Root
CM
$\rightarrow$
Compound
ox.1
white
nù-fì:-hù
'white ox'
b. krò-
fì-
rubber .6
white
CM6 $\rightarrow$ krò-fî:-rì
'white rubber'

f) $-\mathrm{L}+\mathrm{HH} \rightarrow-\mathrm{L}+\mathrm{L} \mathrm{H}$

Only the first syllable is changed into $\mathrm{L}$.
Noun Root +
Adj. Root
$+\mathrm{CM}$
CM6
$\rightarrow$ Compound
a. krò-
sí-
straight
krò-sĩ-rí
rubber.6
sí-
sí-
straight
$\mathrm{CM} 1 \quad \rightarrow \quad$ nũ̀-sĩ̀-nî́
ox.1
'straight ox' 
2.3.2 RepM, RaisL \& SprL rules triggered by words with floating tones. Consider next what happens with floating tones. In this case, RepM, RaisL \& SprL are active and interact, as shown in Table (48) and illustrated below.

\begin{tabular}{|c|c|c|c|c|c|}
\hline \multicolumn{5}{|c|}{ Tonal sandhi rules with floating tones } & \multirow{3}{*}{ Tonal rules } \\
\hline Root, & Tone(s), & & Tones of & & \\
\hline Last Tone & Adj. Roo & $\mathrm{t}+\mathrm{CM}$ & Adjective comp & unds & \\
\hline$-\mathrm{M}(\mathrm{H})$ & $\mathrm{H} \mathrm{H}$ & $/ \mathbf{H} /$ & $-\mathrm{M}+\mathrm{H} \mathrm{H}$ & $/-\mathbf{M}+\mathbf{H} /$ & No change \\
\hline$-\mathrm{M}(\mathrm{H})$ & $\mathrm{L} \mathrm{L}$ & $/ \mathrm{L} /$ & $-\mathrm{M}+\mathrm{M} \mathrm{M}(\mathrm{H})$ & $/-\mathbf{M}+\mathbf{M}(\mathbf{H}) /$ & RaisL \\
\hline$-\mathrm{M}(\mathrm{H})$ & M M (L) & $/ \mathbf{M}(\mathbf{L}) /$ & $-\mathrm{M}+\mathrm{H} \mathrm{H}$ & $/-\mathbf{M}+\mathbf{H} /$ & RepM \\
\hline$-\mathrm{L}(\mathrm{H})$ & M M (L) & $/ \mathbf{M}(\mathbf{L}) /$ & $-\mathrm{L}+\mathrm{H} \mathrm{H}$ & $/-\mathbf{L}+\mathbf{H} /$ & RepM \\
\hline$-\mathrm{M}(\mathrm{L})$ & $\mathrm{L} \mathrm{L}$ & $/ \mathrm{L} /$ & $-\mathrm{M}+\mathrm{LL}$ & $/-\mathbf{M}+\mathbf{L} /$ & No change \\
\hline$-\mathrm{M}(\mathrm{L})$ & $\mathrm{H} \mathrm{H}$ & $/ \mathbf{H} /$ & $-\mathrm{M}+\mathrm{L} \mathrm{H}$ & $/-\mathbf{M}+\mathbf{L H} /$ & SprL \\
\hline$-\mathrm{M}(\mathrm{L})$ & M M(L) & $/ \mathbf{M}(\mathbf{L}) /$ & $-\mathrm{M}+\mathrm{M} \mathrm{M}(\mathrm{L})$ & $/-\mathbf{M}+\mathbf{M}(\mathbf{L}) /$ & No change \\
\hline$-\mathrm{L}(\mathrm{H})$ & & $/ \mathbf{L} /$ & $-\mathrm{L}+\mathrm{L} \mathrm{L}$ & $/-\mathbf{L}+\mathbf{L} /$ & No change \\
\hline
\end{tabular}

The results of the combination of RepM, RaisL \& SprL are similar to those found in the intermediate prosodic word $\omega^{\prime}$ discussed in Section 2.2, except for the following case: In adjectives, the final $(\mathrm{H})$ of $\mathrm{L}(\mathrm{H})$ patterns, like a final anchored $\mathrm{H}$, fails to trigger raising on a following $\mathrm{L} .{ }^{15}$

The tonal rules are exemplified in examples (49) to (56). The examples (49), (53), (55) and (56) show no change in tone.

$$
\text { a) }-\mathrm{M}(\mathrm{H})+\mathrm{HH} \rightarrow-\mathrm{M}+\mathrm{HH}
$$
Noun Root + Adj. Root + CM $\rightarrow \quad$ Compound
a. tīā'- fì- $\quad$ CM1 tīā-fì-hū' pig.1 white'
'white pig'
b. $\quad 1 \overline{5}^{\prime}-$ river.5
fì-
CM5

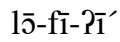
'white river'
b) $-\mathrm{M}(\mathrm{H})+\mathrm{LL} \rightarrow-\mathrm{M}+\mathrm{MM}(\mathrm{H})$
Noun Root $\quad+$ Adj. Root + CM $\rightarrow \quad$ Compound
a. $\quad \mathrm{t} \overline{\mathrm{a}}{ }^{\prime}-$
fì- $\quad$ CM1
tīā-fī-hū'
pig.1
white
'white pig'
b. $\quad \overline{5}^{\prime}-$
fì-
river.5
white
CM5

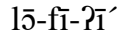
'white river'
c) $-\mathrm{M}(\mathrm{H})+\mathrm{MM}(\mathrm{L}) \rightarrow-\mathrm{M}+\mathrm{HH}$

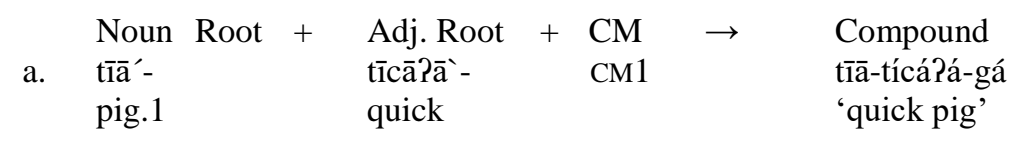

\footnotetext{
${ }^{15}$ We would have expected the following rule: $\mathrm{L}(\mathrm{H})+\mathrm{LL} \rightarrow \mathrm{L}+\mathrm{MM}(\mathrm{H})$ as in nominal compounds. We note that the formation of a M-based contour is avoided as it is in 41(d) illustrated in (45).
} 

b. hīe'-
delivery. 5
tîcā?ā'-
CM5
hīē-tícá?á-gá
quick
'quick delivery'
d) $-\mathrm{L}(\mathrm{H})+\mathrm{MM}(\mathrm{L}) \rightarrow-\mathrm{L}+\mathrm{HH}$

(52)
Noun
a. àplè'-
ladle.3
Adj. Root + CM $\rightarrow$
Compound
ladle. 3
tīcā?ā'-
CM3
àplè-tícá?á-lá
'quick ladle'
b. bàgrà'-
hoe. 5
f
CM5
bàgrà-fว̃́-nว̃
'new hoe'
e) $-\mathrm{M}(\mathrm{L})+\mathrm{LL} \rightarrow-\mathrm{M}+\mathrm{LL}$

(53)
Noun Roo
$+\quad$
Adj. Root + CM $\rightarrow$
Compound
$\begin{array}{ll}\text { a. } & \text { klō` }- \\ & \text { road.5 }\end{array}$
jì̀ें
CM5
klō-jĩ்̀े-lì̃
'red road'
b. kpe'-
fì-
white
CM3
kpē-fî-lì
knife. 3
'white knife'

f) $-\mathrm{M}(\mathrm{L})+\mathrm{HH} \rightarrow-\mathrm{M}+\mathrm{L} \mathrm{H}$

(54)

(55)

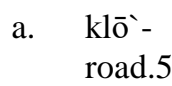
Noun Root +
Adj. Roo
$+\mathrm{CM} \rightarrow$
CM5
Compound
straight
klō-sĩ-nî́
'straight road'
b. kpē'-
knife. 3
sí -
straight
CM3
kpē-sî̀-lî́
'straight knife'
g) $-\mathrm{M}(\mathrm{L})+\mathrm{MM}(\mathrm{L}) \rightarrow-\mathrm{M}+\mathrm{MM}(\mathrm{L} / \mathrm{H})$
a. kpē-
knife. 3
Noun Root +
Adj. Root $+\mathrm{CM}$
$\mathrm{CM} \rightarrow$
Compound
f ̃̄-
$\mathrm{CM} 3$
kpē-fō-lō'
new
'new knife'
b. $\quad \mathrm{c} \bar{\varepsilon}-$
$\quad$ woman. 1
tīcā?ā'-
CM1
ç̄-tīcā?ā-gā'
'quick woman'
quick

h) $-\mathrm{L}(\mathrm{H})+\mathrm{LL} \rightarrow-\mathrm{L}+\mathrm{LL}$
a. gou'-
Noun
go'-
trap 3
Adj. Root + CM
jìे
red
Compound

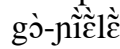
'red trap'
b. àplè' -
$\quad$ ladle .3
fì-
white
CM3
àplè-fî-lì
'white ladle'

To sum up this section, it has been shown that the clusters of rules 'Mid Replacement rule' (RepM), 'Raise Low' (RaisL) \& 'Spreading Low rule' (SprL) apply in different ways in the different 
nominal compounds. Following Ito \& Mester (2013), we assume that the Prosodic Word is a recursive category and that the different morpho-syntactic categories correspond to different levels of Prosodic Words. A nominal root + another nominal root form a different type of prosodic word than a nominal compound formed by a nominal root + an adjectival root. The former kind of nominal compound forms a tighter category that displays more tonal rules than the latter one, even though they are both prosodic words.

\section{Prosodic Phrases}

Until now, the prosodic domains that have been considered were limited to the prosodic word, that was shown to be recursive both in the morphology and in the prosodic structure, as has become evident from the morpho-syntactic structure and the phonological and tonal rules. However, some of the tonal sandhi rules are also active in the higher-level prosodic phrase, as we now turn to demonstrate in this section. Two levels of prosodic phrases are distinguished, the minimal and the maximal one, although it must be clear that further study of the tonal processes in Tagbana may reveal the necessity of additional levels of prosodic constituency.

3.1 Minimal Prosodic phrases. Tagbana sentences have the form shown in (57), the object being preverbal, see Fanselow, Traoré \& Féry (resub.). The canonical structure of the clause is shown in (57).

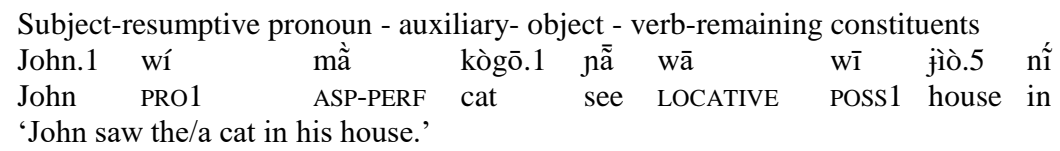

In this section, we concentrate on the relationship between an object and a following verb, which is very tight, but not as tight as the one that we found in the prosodic word. The prosodic domain that includes object + verb is called the minimal prosodic phrase $\left(\Phi^{\mathrm{min}}\right)$. Spreading $\mathrm{L}$ rule but also Spreading H rule apply in this domain, and RepM or RaisL rule do not. This is compatible with the observation that the larger prosodic domains have less tonal changes than the smaller ones. The spreading rules in words with linked tones are summed up in Table (58) and illustrated in examples (59) to (64) in the next subsection 3.1.1. In Subsection 3.1.2 it will be shown that the same spreading rules apply in words with floating tones.

3.3.1 Spreading of $H$ and Spreading of $L$. In Table (58), the verb form is the 'infinitive' form, that is the citation form of the verb and its base form in conjugations. The main tonal patterns are: $\mathrm{H} / \mathrm{H} /$, $\mathrm{M} / \mathrm{M} /, \mathrm{L} / \mathrm{L} /$ for monosyllabic forms and $\mathrm{HH} / \mathrm{H} /, \mathrm{MM} / \mathrm{M} /, \mathrm{LH} / \mathrm{LH} /$ for dissyllabic forms. ${ }^{16} \mathrm{HL}$, $\mathrm{MH}$ or $\mathrm{LL}$ are not found in infinitive.

\footnotetext{
${ }^{16}$ Floating tones are not involved in infinitive. There is no $\mathrm{M}(\mathrm{L})$ with a final fall. MM infinitive verbs are realized with a flat mid contour in isolation as well as at the end of a verb phrase. There is no reason to suspect the possibility of a $(\mathrm{H})$, even if we cannot use spreading rules as indicative of $(\mathrm{H})$, due to the position of verbs at boundaries blocking spreading rules.
} 
(58) Spreading triggered by $\mathrm{H}$ and $\mathrm{L}$

\begin{tabular}{|c|c|c|c|c|c|c|}
\hline \multicolumn{2}{|c|}{ Object, last tone } & \multicolumn{2}{|c|}{ Tone(s), verb } & \multicolumn{2}{|c|}{ Tones Obj+verb } & \multirow{2}{*}{$\begin{array}{l}\text { Spreading Rules } \\
\text { No change }\end{array}$} \\
\hline a. & $-\mathrm{H}$ & $\mathrm{H}$ & $/ \mathbf{H} /$ & $-\mathrm{H \# H}$ & /-H\#H/ & \\
\hline & $-\mathrm{H}$ & $\mathrm{HH}$ & $/ \mathbf{H} /$ & -H\#HH & /-H\#H/ & No change \\
\hline b. & $-\mathrm{H}$ & $\mathrm{L}$ & $/ \mathrm{L} /$ & $-\mathrm{H \# H}$ & /-H\#H/ & SprH \\
\hline & $-\mathrm{H}$ & LH & $/ \mathbf{L H} /$ & -H\#HH & /-H\#H/ & SprH \\
\hline c. & $-\mathrm{L}$ & $\mathrm{L}$ & $/ \mathbf{L} /$ & -L\#L & /-L\#L/ & No change \\
\hline & $-\mathrm{L}$ & $\mathrm{LH}$ & $/ \mathbf{L H} /$ & -L\#LH & /-L\#LH/ & No change \\
\hline d. & $-\mathrm{L}$ & $\mathrm{H}$ & $/ \mathbf{H} /$ & -L\#L & /-L\#L/ & SprL \\
\hline & $-\mathrm{L}$ & $\mathrm{HH}$ & $/ \mathbf{H} /$ & -L\#LH & /-L\#LH/ & SprL \\
\hline e. & $-\mathrm{H}$ & M & $/ \mathbf{M} /$ & $-\mathrm{H \# M}$ & /-H\#M/ & No change \\
\hline & $-\mathrm{H}$ & MM & $/ \mathbf{M} /$ & -H\#MM & /-H\#M/ & No change \\
\hline f. & $-\mathrm{L}$ & M & $/ \mathbf{M} /$ & -L\#M & /-L\#M/ & No change \\
\hline & $-\mathrm{L}$ & MM & $/ \mathbf{M} /$ & -L\#MM & /-L\#M/ & No change \\
\hline
\end{tabular}

RepM and RaisL are both absent in this constituent, which confirms that they are linked. The suppression of M by RepM leaves the field open for RaisL to generate M contours.

We find here two symmetrical rules: Spreading $\mathrm{H}(\mathrm{SprH})$ which spreads a $\mathrm{H}$ onto a L, see (58)b and Spreading L (SprL) which spreads a L onto a H (SprL), see (58)d. M tones are left untouched by the rules operating in this domain.

As before, each case of Table (58) is illustrated with examples.

a) $-\mathrm{H}+\# \mathrm{H} \rightarrow-\mathrm{H} \# \mathrm{H}$ and $-\mathrm{H}+\# \mathrm{HH} \rightarrow-\mathrm{H} \# \mathrm{HH}$
kó
$\rightarrow \quad$ Nominal Objet + Verb
a. fúó. 1
unearth
fíś kó
fish.1
'unearth fish'
pé:ré
b. ákpá
rice. 1
sell
ákpá pé:ré
'sell rice'
b) $-\mathrm{H}+\# \mathrm{~L} \rightarrow-\mathrm{H} \# \mathrm{H}$ and $-\mathrm{H}+\# \mathrm{LH} \rightarrow-\mathrm{H} \# \mathrm{HH}$

(60)
$\begin{array}{lll}\text { Noun } & +\quad \begin{array}{l}\text { Verb } \\ \text { cò }^{17}\end{array}\end{array}$
fish.1
catch
$\rightarrow \quad$ Nominal Objet + Verb
b. ákpá
tì̀:rí
rice. 1
share
fíó có
'catch fish'
c) $-\mathrm{L}+\# \mathrm{~L} \rightarrow-\mathrm{L} \# \mathrm{~L}$ and $-\mathrm{L}+\# \mathrm{LH} \rightarrow-\mathrm{L} \# \mathrm{LH}$

(61)
$\begin{array}{lll}\text { Noun } & +\quad \begin{array}{l}\text { Verb } \\ \text { nãdò-?ò } \\ \text { yam-CM5 }\end{array} & \text { cò } \\ \text { catch }\end{array}$
$\rightarrow \quad$ Nominal Objet + Verb
nãdò?ò cò
'catch yam'
b. krò-?j̀
sà:rá
pay
car-CM5
krò?ò sà:rá
pay transportation'

\footnotetext{
${ }^{17}$ This form is the citation form of the verb and its base form in conjugations. We did not translate it by an infinitive (for example 'to catch') as it does not have the same function as an English infinitive.
} 
d) $-\mathrm{L}+\# \mathrm{H} \rightarrow \mathrm{L} \#-\mathrm{L}$ and $-\mathrm{L}+\# \mathrm{HH} \rightarrow-\mathrm{L} \# \mathrm{LH}$

(62)
Noun + Verb
a. nằdò-?ò kó
yam-CM5 unearth
$\rightarrow \quad$ Nominal Objet + Verb
nằdò?ò kò
'harvest yam'
b. krò-?̀̀ pé:ré
car-CM5 sell
krò?ว̀ pè̀:ré
'sell car'

e) $-\mathrm{H}+\mathrm{M} \rightarrow \mathrm{H} \# \mathrm{M}$ and $-\mathrm{H} \# \mathrm{MM} \rightarrow-\mathrm{H} \# \mathrm{MM}$

(63)
Noun + Verb
a. cã́-lấ cā
market-CM5 look for
$\rightarrow \quad$ Nominal Objet + Verb
cấlá̃ cā
'look for market'
b. wrí-?í

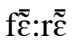
smoke-CM5
press

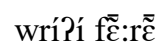
'press smoke'

f) $-\mathrm{L}+\mathrm{M} \rightarrow \mathrm{L} \# \mathrm{M}$ and $-\mathrm{L} \# \mathrm{MM} \rightarrow-\mathrm{L} \# \mathrm{MM}$

(64)
a. sìà:-là fī̄
tire-CM3 blow
Noun + Verb
b. kà-?à j jēle
village-CM5 clean
Nominal Objet + Verb
sìal fî̄ $\bar{\varepsilon}$
'inflate tire'
kà?à $\mathrm{j} \bar{\varepsilon} \mathrm{l} \bar{\varepsilon}$
'clean village'

3.3.2 Spreading triggered by floating $(H)$ or $(L)$ tones. SprH and SprL apply with floating tones as well.

(65) Spreading triggered by floating $(\mathrm{H})$ or $(\mathrm{L})$ tones

\begin{tabular}{|c|c|c|c|c|c|}
\hline \multicolumn{2}{|c|}{ Object, last tones } & \multicolumn{2}{|c|}{ Tones, verb } & Tones Obj+verb & \multirow{2}{*}{$\begin{array}{l}\text { Spreading Rules } \\
\text { No change }\end{array}$} \\
\hline a. & $-\mathrm{L}(\mathrm{H})$ & $\mathrm{H}$ & /H/ & /-L\#H/ & \\
\hline & $-\mathrm{L}(\mathrm{H})$ & $\mathrm{HH}$ & $/ \mathrm{H} /$ & -L\#HH /-L\#H/ & No change \\
\hline \multirow[t]{2}{*}{ b. } & $-\mathrm{L}(\mathrm{H})$ & $\mathrm{L}$ & $/ \mathrm{L} /$ & /-L\#H/ & SprH \\
\hline & $-\mathrm{L}(\mathrm{H})$ & LH & /LH/ & -L\#HH /-L\#H/ & $\mathrm{SprH}$ \\
\hline \multirow[t]{2}{*}{ c. } & $-\mathrm{L}(\mathrm{H})$ & M & $/ \mathbf{M} /$ & /-L\#M/ & No change \\
\hline & $-\mathrm{L}(\mathrm{H})$ & $\mathrm{MM}$ & $/ \mathbf{M} /$ & -L\#MM /-L\#M/ & No change \\
\hline \multirow[t]{2}{*}{ d. } & $-\mathrm{M}(\mathrm{H})$ & $\mathrm{H}$ & $/ \mathbf{H} /$ & /-М\#H/ & No change \\
\hline & $-\mathrm{M}(\mathrm{H})$ & $\mathrm{HH}$ & $/ \mathrm{H} /$ & -М\#НH /-М\#Н/ & No change \\
\hline \multirow[t]{2}{*}{ e. } & $-\mathrm{M}(\mathrm{H})$ & $\mathrm{L}$ & $/ \mathrm{L} /$ & /-М\#H/ & SprH \\
\hline & $-\mathrm{M}(\mathrm{H})$ & $\mathrm{LH}$ & $/ \mathbf{L H} /$ & -М\#НH /-М\#Н/ & $\mathrm{SprH}$ \\
\hline \multirow[t]{2}{*}{ f. } & $-\mathrm{M}(\mathrm{H})$ & M & /M/ & /-M\#M/ & No change \\
\hline & $-\mathrm{M}(\mathrm{H})$ & MM & $/ \mathbf{M} /$ & -M\#MM /-M\#M/ & No change \\
\hline \multirow[t]{2}{*}{ g. } & $-\mathrm{M}(\mathrm{L})$ & $\mathrm{L}$ & $/ \mathrm{L} /$ & -M\#L /-M\#L/ & No change \\
\hline & $-\mathrm{M}(\mathrm{L})$ & $\mathrm{LH}$ & /LH/ & -M\#LH /-M\#LH/ & No change \\
\hline \multirow[t]{2}{*}{ h. } & $-\mathrm{M}(\mathrm{L})$ & $\mathrm{H}$ & /H/ & /-M\#L/ & SprL \\
\hline & $-\mathrm{M}(\mathrm{L})$ & $\mathrm{HH}$ & $/ \mathbf{H} /$ & /-M\#LH/ & SprL \\
\hline \multirow[t]{2}{*}{ i. } & $-\mathrm{M}(\mathrm{L})$ & & $/ \mathbf{M} /$ & /-M\#M/ & No change \\
\hline & $-\mathrm{M}(\mathrm{L})$ & MM & /M/ & -М\#MM /-M\#M/ & No change \\
\hline
\end{tabular}


a) $-\mathrm{L}(\mathrm{H})+\# \mathrm{H} \rightarrow-\mathrm{L} \# \mathrm{H}$ and $-\mathrm{L}(\mathrm{H})+\# \mathrm{HH} \rightarrow-\mathrm{L} \# \mathrm{HH}$

(66)
Noun + Verb $\quad \rightarrow \quad$ Nominal Objet + Verb
a. àplè' kó àplè kó
ladle.3 unearth 'unearth a ladle'
b. bàgrà-?à' pé:ré bàgrà? pé:ré
hoe-CM5 sell 'sell a hoe'
b) $-\mathrm{L}(\mathrm{H})+\# \mathrm{~L} \rightarrow-\mathrm{L} \# \mathrm{H}$ and $-\mathrm{L}(\mathrm{H})+\# \mathrm{LH} \rightarrow-\mathrm{L} \# \mathrm{HH}$

(67)
a. àplè' cò
ladle.3 catch
$\rightarrow \quad$ Nominal Objet + Verb
Verb àplè có
b. bàgrà-?à' tî̀:rî́ hoe-CM5 share
bàgrà? tî́:rî́
'share a hoe'
c) $-\mathrm{L}(\mathrm{H})+\# \mathrm{M} \rightarrow-\mathrm{L} \# \mathrm{M}$ and $-\mathrm{L}(\mathrm{H})+\# \mathrm{MM} \rightarrow-\mathrm{L} \# \mathrm{MM}$

(68)
a. àblò-?ò' sīo
peanut-CM5 buy
Noun + Verb
àblò? sī̄
'buy a peanut'
$\rightarrow \quad$ Nominal Objet + Verb
b. àplè’.3
$\mathrm{j} \bar{\varepsilon} \bar{\varepsilon} \bar{\varepsilon}$
ladle
clean
d) $-\mathrm{M}(\mathrm{H})+\# \mathrm{H} \rightarrow-\mathrm{M} \# \mathrm{H}$ and $\mathrm{M}(\mathrm{H})+\# \mathrm{HH} \rightarrow-\mathrm{M} \# \mathrm{HH}$

(69)
a. tī-? $\overline{1}^{\prime} \quad$ kó
tree-CM5 unearth
Noun + Verb
$\rightarrow \quad$ Nominal Objet + Verb
tīê̄ kó
'unearth a tree'
b. ājī̄̄: $1 \overline{5}^{\prime} \quad$ pé:ré tumbler-CM3 sell
àj̄̄̄̄:l̄̄ pé:ré 'sell a tumbler'
e) $-\mathrm{M}(\mathrm{H})+\# \mathrm{~L} \rightarrow-\mathrm{M} \# \mathrm{H}$ and $-\mathrm{M}(\mathrm{H})+\# \mathrm{LH} \rightarrow-\mathrm{M} \# \mathrm{HH}$

(70)
$\begin{aligned} & \text { Noun } \\ & \text { a. } \mathrm{t}^{\mathrm{i}}-\mathrm{P}^{\prime}\end{aligned}+\underset{\text { Cò }}{\text { corb }}$
tree-CM5 catch
$\rightarrow \quad$ Nominal Objet + Verb
b. $\bar{a} \cdot \bar{\jmath} \overline{1}: 1^{\prime}$
tî̀:rí
tumbler-CM3 share
tī̄ī có
'catch a tree'
àjī̄o: $1 \bar{\jmath}$ tî́:rî́
'share a tumbler'
f) $-\mathrm{M}(\mathrm{H})+\# \mathrm{M} \rightarrow-\mathrm{M} \# \mathrm{M}$ and $-\mathrm{M}(\mathrm{H})+\# \mathrm{MM} \rightarrow-\mathrm{M}$ \# MM

(71)

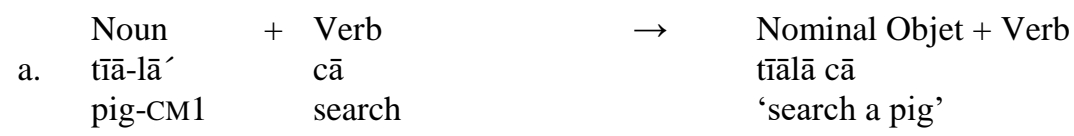



b. $\mathrm{t} \overline{\mathrm{i}}-\mathrm{P} \overline{\mathrm{i}} \mathrm{\prime}$
$\mathrm{j} \bar{\varepsilon} \mathrm{l} \bar{\varepsilon}$
tī? $\overline{1} \mathrm{j} \bar{\varepsilon} \mathrm{l} \bar{\varepsilon}$
tree-CM3
clean
'clean a tree'

g) $-\mathrm{M}(\mathrm{L}) \# \mathrm{~L} \rightarrow-\mathrm{M}+\mathrm{L}$ and $-\mathrm{M}(\mathrm{L}) \# \mathrm{LH} \rightarrow-\mathrm{M}+\mathrm{LH}$

(72)
Noun + Verb
a. kē:-rē' cò
field-CM6 catch
$\rightarrow \quad$ Nominal Objet + Verb
kē:rē cò
'catch a field'

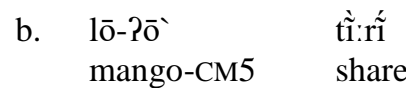
lō?ō tî̀:rî́
'share a mango'

h) $-\mathrm{M}(\mathrm{L}) \# \mathrm{H} \rightarrow-\mathrm{M}+\mathrm{L}$ and $-\mathrm{M}(\mathrm{L}) \# \mathrm{HH} \rightarrow-\mathrm{M} \# \mathrm{LH}$
Noun + Verb
a. kē:-rē' kû́
field-CM6 cut
$\rightarrow \quad$ Nominal Objet + Verb
kē:rē kü
'cut a field'
b. $\quad \overline{0}-? \overline{0}$
pé:ré
lōPō pè:ré
mango-CM5 sell
sell a mango'
i) $-\mathrm{M}(\mathrm{L})+\# \mathrm{M} \rightarrow-\mathrm{M} \# \mathrm{M}$ and $-\mathrm{M}(\mathrm{L})+\# \mathrm{MM} \rightarrow-\mathrm{M}$ \# MM
Noun + Verb
a. kē:-rē' sīō
field-CM6 buy
$\rightarrow$
Nominal Objet + Verb
kē:rē-sī̄o ${ }^{18}$
'buy a field'
b. kē:-rēè
kã̃lã
field-CM6
weed
kē:rē -kã̄lã
'weed a field'

Summing up, only one cluster of symmetrical rules (SprL and SprH) applies in the Minimal Prosodic phrase that is mapped to a verbal phrase (object plus verb), RepM and RaisL are inactive is in this domain.

3.2 Maximal Prosodic Phrases. The next prosodic domain is the Maximal Prosodic Phrase $\left(\Phi^{\max }\right)$. $\Phi^{\max }$ are made up of VPs, but also lexical subjects and adjuncts, as illustrated in (75). An example appears in (76). No tonal sandhi rules apply across Maximal Prosodic Phrases. In other words, no

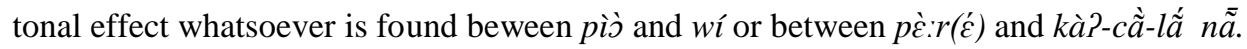

$$
\underset{\Phi^{\max }}{\left.(\text { Nominal subject })_{\mathrm{DP}}+(\mathrm{PRO}+\mathrm{AUX}+\text { object }+ \text { verb })_{\mathrm{VP}}+\underset{\Phi^{\max }}{(\text { adjunct }}\right)_{\mathrm{AP} / \mathrm{PP}}}
$$

\footnotetext{
${ }^{18}$ kê:rê-sīō can also be realized: kē:rè-sī̄o, that is with a slight final fall at the end of kē:rè and a slight lowering

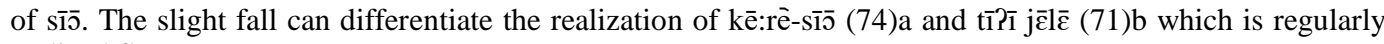
realized flat.
} 
(76) Maximal prosodic phrases
$\left(\Phi^{\max }\right)\left(\Phi^{\max }\right.$

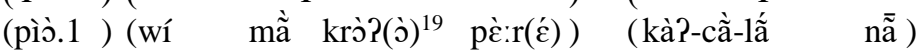
child PRO1 ASP car sell village-market LOC
'The child sold the car at the market of the village'

Summing up and stressing the main point, there is no sandhi rule across Maximal Prosodic Phrases.

\section{Intonational Phrases}

The highest prosodic domain in the prosodic hierarchy in (6) is the Intonation Phrase, that can be considered as corresponding to a clause. In many languages, final intonational patterns specify the modality of the sentence, as is the case in Tagbana. In Tagbana, a yes-no question, as illustrated in (77), can be marked by a segmental morpheme or by a lax intonation (Clements \& Rialland 2007, Rialland 2007). This lax question intonation consists of lengthening of the last vowel with its tone. However, it must be noted that a lax question intonation is not obligatory in a yes-no question, since it is also possible to insert a final question particle at the end of the sentence. In all cases, the word order is not affected by the modality of the sentence.
Assertion v. Question
a. pì̀.1 wí ké:ré
child PRO1 go
'The child went.'
b. pì̀.1 wí kéré jó
child PRO1 go Q
'Did the child go?'
c. pì̀.1 wí kéré:
child PRO1 go
'Did the child go?'

Intonational phrases are also domains of downdrift processes but no tonal sandhi rules are related to this highest level of the prosodic hierarchy.

\section{Conclusion and Summary}

The contribution of this article is two-fold as it concerns the whole tonal system, including the relationship between the sandhi tone rules, and the organisation of the prosodic hierarchy.

It has been shown that Tagbana has not only three level tones (L, M, H) but also two floating tones $(\mathrm{H})$ and $(\mathrm{L})$. Floating tones are always word-final and manifest themselves on a following word in specific syntactic and prosodic contexts. We found that a $\mathrm{M}$ tone at the end of a noun is always followed by a floating tone (either $\mathrm{H}$ or L), which might be a historic trace left by the tone of a Class Marker.

\footnotetext{
${ }^{19}$ In this example, the vowels in parenthesis are elided, leaving their tone floating. The $\mathrm{H}$ of pè $\mathrm{r}(\dot{\varepsilon})$ is not realized and does not influence the realization of the following $\left(\Phi^{\max }\right)$.
} 
We identified the following sandhi tonal rules: Mid Replacement rules' (RepM), 'Raising of L' (RaisL), 'Spreading of L' (SprL) and 'Spreading of H' (SprH). In RepM rules, a M(H/L) pattern is replaced by a preceding $\mathrm{L}$ or $\mathrm{H}$ tone. Sequences of $\mathrm{M}$ behave as a single $\mathrm{M}$ associated to several syllables. 'Raising of L' (RaisL) raises a $L$ to a $M(H)$. 'Spreading of L' (SprL) refers to spreading of a $\mathrm{L}$ on a following $\mathrm{H}$ and 'Spreading of H' (SprH) to spreading of a $\mathrm{H}$ on a following L tone.

The domains of the sandhi tonal rules were studied in some detail. In the smallest domains that were considered, the Minimal Prosodic Word $\omega^{\mathrm{min}}$, the final linked tone of the lexical root is spread on the unspecified vowel slot of the Class Marker and the floating tone of the lexical root, if there is any, is aligned with the end of the word.

On the next level, the Intermediate Prosodic Word $\omega^{\prime}(\mathrm{N}+\mathrm{N}$ compound $)$, the rule clusters RepM, RaisL and SprL apply regularly, both with linked and with floating tones. In the Maximal Prosodic Word $\omega^{\max }(\mathrm{N}+\operatorname{Adj}$ and $\mathrm{N}+\mathrm{V})$, RepM is pervasive but at this level, RaisL and SprL applies only partly to linked tones while being regular with floating tones. RepM is present in all nominal compounding processes and is limited to these processes. In the minimal Prosodic Phrase (Object + Verb), SprL and SprH apply regularly. No tonal sandhi takes place in the Intonation Phrase. Thus, tonal sandhi rules are present at many levels of the Prosodic Hierarchy and their number and nature is related to the position of the constituent within this hierarchy, with a tendency towards a simplification as the constituents get larger, from the Intermediate Prosodic Word - $(\mathrm{N}+$ $\mathrm{N}$ compound) - to the Intonational Phrase.

In line with this article, further research has to be done. Thus, we did not investigate the verbal tonology including the tones of the TAM (Tense-Aspect-Markers) which might also involve floating tones. Nominal tonology has also to be completed by a study of nouns with more complex tonal root patterns in various contexts.

\section{Acknowledgements}

We are very grateful to an anonymous reviewer for in-depth and detailed comments and suggestions that helped us to improve the article and to Larry Hyman who helped Yranahan Traoré to better grasp the intricacies of the tonal system of Tagbana. Finally our thanks also go to James Essegbey for his editorial work.

\section{References}

Asongwed, Tah \& Larry M. Hyman. 1976. Morphotonology of the Ngamambo Noun. Studies in Bantu Tonology, Southern California Occasional Papers in Linguistics 3. 23-46.

Bodomo, Adams, Hasiyatu Abubakari \& Dewei Che. 2018. On nominalizing the serial verbs the serial verb in Mabia languages, Ghana Journal of Linguistics 7.2. 1-32.

Carlson, Robert. 1994. A Grammar of Supyire. Mouton de Gruyter, Berlin

Clamens. R.P. 1952. Essai de Grammaire Senufo taBwana. Bulletin de l'Institut Francophone de l'Afrique Noire XIV. no. 4. 1402-1465.

Fanselow, Gisbert, Yranahan Traoré \& Caroline Féry (resubmitted). The object position in Tagbana. University of Potsdam and University of Frankfurt.

Garber, Ann Elizabeth. 1987. A tonal analysis of Senufo: Sucite dialect, Ph.D. University of Illinois, Urbana-Champaign.

Heath Jeffrey, Aminata Ouattara \& Abbie Hantgan. 2017. Short grammar of Tiefo- $N$ of Nyafogo

(Gur, Burkina Faso). https://deepblue.lib.umich.edu/handle/2027.42/139024 
Hyman, Larry. 1993. Register tones and tonal geometry. In: The phonology of tone: The representation of tonal register. Van der Hulst Harry \& Keith Snider (eds.). Mouton de Gruyter, Berlin.

Hyman, Larry. 2014. How To Study a Tone Language, with exemplification from Oku (Grassfields Bantu, Cameroon). Language documentation and conservation 8. 525-562.

Hyman, Larry \& Maurice Tadadjeu. 1976. "Floating Tones in Mbam-Nkam", in L.M. Hyman (ed.), Studies in Bantu Tonology, Southern California 0ccasional Papers. 51-111.

Ito, Junko \& Armin Mester. 2013. Prosodic subcategories in Japanese. Lingua 124. 20-40.

Katia Kamara, Casimir. 1988. Lexikon der Tagbana-sprache, Ph.D. University of Bielefeld.

Kanga Ega, Danielle. No date. La syntaxe au secours de la phonologie en tagbana. Manuscript. Université Houphouët Boigny, Abidjan, Côte d'Ivoire. http://ltml.univ-fhb.edu.ci/wpcontent/uploads/files/article11/DanielleKANGA-EBA.pdf

Kabore, Raphael. 1985. Essai d'analyse de la langue mòvré (parler de Ouagadougou). Publications du Laboratoire de Linguistique formelle (Paris 7), Paris.

Kone, Kiyofan Antoine. 2015. Semantic analysis of the use of classifiers in Tagbana, Ph.D. University of Laval (Canada).

Ladd. D. Robert 1986. Intonational Phrasing: The Case for Recursive Prosodic Structure. Phonology Yearbook 3. 311-340.

Odden, David. 1988. Floating tones and contour tones in Kenyang, Studies in African Linguistics 19.1. 1-34. https://journals.linguisticsociety.org/elanguage/sal/article/view/1213.html

Ouoba, Bendi. 1982. Description systématique du gulmancema: phonologie, lexicologie, syntaxe, Ph.D. University of Paris 3.

Njantcho Kouagang, Elisabeth. 2018. Grammaire du kwakum, Ph. D thesis, INALCO, Paris

Some, Penou-Achille. 1982. Systématique du signifiant en Dagara : variété Wulé, L'Harmattan, Paris.

Traoré, Yranahan. 2020. The morphology and phonology of the nominal domain in Tagbana. Peter Lang Verlag, Bern.

Traoré, Yranahan \& Caroline Féry. 2018. Nominal classes and phonological agreement in Frò?ò (Tagbana). In: Hano-Bana: A Festschrift for Junko Ito and Armin Mester. Ryan Bennett, Andrew Angeles, Adrian Brasoveanu, Dhyana Buckley, Nick Kalivoda, Shigeto Kawahara, Grant McGuire, Jaye Padgett (Eds.). University of California, Santa Cruz. 1-29.

Traoré, Yranahan \& Caroline Féry. 2019. Syllable structure and loanword adaptation in Frò?ò. In: Lotven, Samson, Silvina Bongiovanni, Phillip Weirich, Robert Botne and Samuel Gyasi Obeng, eds. African linguistics across the disciplines. Selected papers from the $48^{\text {th }}$ Annual Conference on African Linguistics. Language Science Press. www.github.com/langsci/226.

Vydrin, Valentin. 2016. Towards a proto-Mande reconstruction and an etymological dictionary, In Comparatisme et reconstruction: tendances actuelles, Podzniakov (ed.), Faits de langues, Peter Lang, Bern.

Annie Rialland

Laboratoire de phonétique et phonologie, UMR 7018 (CNRS/Sorbonne-Nouvelle), Paris annie.rialland@sorbonne-nouvelle.fr

Yranahan Traoré, Caroline Féry

Institute of Linguistics, Goethe-Universität, Frankfurt

yranahan@gmail.com, caroline.fery@gmail.com 